\title{
Introduction
}

\section{Aspects of the Ottoman Twilight}

In Turkey's collective memory today, the Ottomans lost the First World War; the Turks won it.

Mustafa Aksakal, "The Ottoman Empire"1

Remembering is a very private act. Yet there are certain watersheds in history when private remembrance and collective memory overlap. In my generation everybody remembers exactly where they were and what they were doing when they heard the news of the assassination of John Fitzgerald Kennedy. For later generations it will be 9/11. For Eric Hobsbawm, it was when he and his sister were returning home from school in Berlin and they saw newspapers with banner headlines declaring that Adolf Hitler had become the Chancellor of Germany, "I can see it still as in a dream," Hobsbawm said. ${ }^{2}$ For most Arabs in the late Ottoman Empire the watershed moment was the hanging of Arab patriots by Cemal Pasha in 1915 and 1916. The collective "shudder that shook the country", as memorably put by George Antonius, was transmitted across generations and has become the definitive moment in Arab-Turkish relations that shaped the collective memory of Arabs who saw the "days of the Turks" as a period of unmitigated catastrophe and destitution. ${ }^{3}$ As admirably expressed by Salim Tamari:

1 Mustafa Aksakal, "The Ottoman Empire," in The Cambridge History of the First World War, ed. Jay Winter (Cambridge: Cambridge University Press, 2014), vol. 1, 464.

2 Eric Hobsbawm, Interesting Times: A Twentieth-Century Life (London: Allen and Unwin, 2002), 74.

3 George Antonius, The Arab Awakening: The Story of the National Arab Movement (London and New York: Kegan Paul, 2000), 190. 
The Great War brought about a radical break with the Ottoman past in the whole Arab East, not only in the established constitutional regime but also in the system of governance, local administration, and identity politics. In popular memory of peasants and city folk alike, 1915 was the Year of the Locust ('am al Jarad). Even four generations later, the locust invasion continues to evoke the combined memory of natural disasters and the manmade devastation of war. These events erased four centuries of rich and complex Ottoman patrimony in which popular narratives of war and nationalist ideology colluded. An anti-Ottoman rewriting of history took place simultaneously, and in the same abrupt manner, both on the Turkish side (in the guise of the modernizing state and making it geographically manageable) and on the Arab side (in the sustained annals of nationalist historiography). The erasure replaced four centuries of relative peace and dynamic activity, the Ottoman era, with what was known in Arabic discourse as "the days of the Turks": four miserable years of tyranny symbolized by the military dictatorship of Ahmad Cemal Pasha in Syria, seferberlik (forced conscription and exile), and the collective hanging of Arab patriots in Beirut's Burj Square on August 15, 1916. ${ }^{4}$

The last few years of Ottoman rule in Lebanon and Syria are known as the "eyyam-atrak" the "days of the Turks." This term usually carries dark connotations, being associated with famine, the hanging of the martyrs in Burj Square, and Cemal Pasha's reign of terror. All these events are usually described from the perspective of the local population; as such they have a very important place in the formation of what has come to be recognized as the "collective memory" of a people. Leila Fawaz astutely points out that many Arab autobiographers who mostly wrote for their family circles, nonetheless "refer to shared experiences, myths, and recollections of the past" that were handed down over generations. ${ }^{5}$ But how did the "atrak" themselves see their position in Lebanon, Syria, Palestine, and the Hijaz in the final years of the Great War?

This book will attempt to address this question based on Ottoman memoirs written by eyewitnesses to the last years of Ottoman rule. It aims to be a critical annotated edition of the memoirs contained within

4 Salim Tamari, The Year of the Locust. A Soldier's Diary and the Erasure of the Ottoman Past (Berkeley, Los Angeles and London: University of California Press, 2011), 5.

5 Leila Fawaz, The Land of Aching Hearts: The Middle East in the Great War (Cambridge Massachusetts and London: Harvard University Press, 2014), 235. 
it, cross-referencing them and putting them in a historical context. The memoirs will be cited in extenso, given that the aim is to provide a reference work for readers who do not read Turkish, and given that most of these texts are only available in Turkish.

In all five of the memoirs cited in this work, at the time of writing the authors had shared a similar recent past. In the late 1890s a secret society had formed among young Ottoman officers, doctors, lawyers, and intellectuals whose aim was to bring an end to the despotism of Sultan Abdulhamid II (r. 1876-1909) and restore the constitution of 1878. This secret society would ultimately be named The Committee of Union and Progress (CUP) and would eventually come to be dubbed the Young Turks. ${ }^{6}$ The CUP eventually spread to include a very broad spectrum of the late Ottoman elite and would lead the Revolution of 1908 which restored the constitution. A counter coup in April 1909 led to the deposition of Sultan Abdulhamid. The last free elections of 1912 were followed by a military coup in 1913, after which the empire was effectively ruled by the CUP. The leadership of 1913 would ultimately be winnowed down to the infamous ruling Triumvirate of Enver Pasha, Talat Pasha, and Cemal Pasha. When the clouds of war started to gather in Europe, the leadership of the Young Turks saw the war as an opportunity to recover lost territory and build a strong state. As elegantly put by Mustafa Aksakal: "The new Ottoman leadership of the twentieth century viewed Great Power diplomacy as a fixed game: the Great Powers were the House, and you could not beat it by playing by the rules." Diplomacy had had its day, the only solution was military. After shopping around for allies among the European powers, the Young Turks signed an alliance with Germany on October 29, 1914. The Ottoman Empire entered the war on November 2.

The commonly accepted, official narrative in the early years of the Republic of Turkey was that the Young Turks dragged the Ottoman Empire into the war and thus to its destruction, or that they had been tricked by

6 There is an extensive literature on the Young Turks and the CUP. A few of the better known works are the following: Feroz Ahmad, The Young Turks: The Committee of Union and Progress in Turkish Politics 1908-1914 (Oxford: Oxford University Press, 1969); Şükrü Hanioğlu, Preparation for a Revolution: The Young Turks, 1902-1908 (New York: Oxford University Press, 2001); Şükrü Hanioğlu, The Young Turks in Opposition (New York: Oxford University Press, 1995).

7 Mustafa Aksakal, The Ottoman Road to War in 1914: The Ottoman Empire and the First World War (Cambridge and London: Cambridge University Press, 2008), 9. The CUP would also be referred to as the "Ittihadists" (Ittihatçılar). 
the Germans. A new generation of historians has now completely revised this position. Notably, Mustafa Aksakal and others have shown that the Ottoman Empire's entry into the war was the result of a conscious decision which was backed by almost all of the Ottoman elite rather than a small coterie of Young Turks. ${ }^{8}$

Many people within the Ottoman Empire in the years leading up to the war were obsessed with the loss of the Balkan Provinces (Rumeli) and the belief that they were besieged by enemies. The Balkan Wars (1911-1913) were a particularly traumatic memory as many of the Young Turk cadres were from the Balkans. They particularly resented the fact that the European powers were not at all concerned over the aggression meted out by the Balkan states toward Muslim populations. This feeling hovers like a shadow in all the memoirs cited in this book. Hüseyin Kazım, whom we will meet below, was one of the core group that founded the CUP. In a small pamphlet written in 1914 he condemned the Albanians for being responsible for the "Balkan Alliance" (Balkan İttifakı). ${ }^{9}$ Falih Rifkı was a fiery young writer for the official CUP newspaper Tanin. Rifkı would bemoan the loss of Rumeli, which he felt was the true home of the Turks, and lament over his belief that they would always be strangers in the Arab lands: "The air of Lebanon is a hundred times more foreign for us than the air of Dobruca." Münevver Ayaşl, who was from Salonica, would grieve over the loss of her beloved home town. Naci Kıcıman would agonize over the "Anatolian lads" who were being sacrificed to defend the Arabian desert.

The official publication of the Turkish General Staff castigated the Arabs as cowardly and disloyal. All of our authors were writing and publishing in the intellectual milieu of the Kemalist republic, whose attitude to the loss of the Arab lands I will define below as the "good riddance syndrome."

The most important central actor in the creation of this negative image of the "atrak" was undoubtedly Cemal Pasha. One of the Young Turk triumvirate, together with Enver and Talat, Cemal Pasha had been appointed the Commander of the Fourth Army District (essentially Syria, Palestine and Lebanon) where he enjoyed almost dictatorial powers. ${ }^{10}$ One of his

8 Ibid., 57-92.

9 Ebru Boyar, Ottomans, Turks and the Balkans. Empire Lost, Relations Altered (New York: Tauris Academic Studies, 2007), 40, 91.

10 The exact date of his appointment is unclear. On November 18, 1914 he sent Enver a telegram where he signs himself as "Commander of the Fourth Army." On December 13, 1917 he left Damascus for good. My thanks to Talha Çiçek for this information. 
close aids would ironically refer to him as "Viceroy of Syria" although the Ottoman high command had no such official rank. ${ }^{11}$ During the three years (1914-1917) in which he ruled Syria with an iron fist, Cemal set up a reign of terror and became infamous for the trial and execution of some forty Arab nationalists whom he accused of sedition. Recent scholarship has somewhat revised this negative image of Cemal but the image of the "iron fist" and the "reign of terror" still prevails. Thus Cemal Pasha came to symbolize much more than the executioner of the Arab patriots, he became a figure symbolizing the "four hundred years of decadence" of Turkish rule, "which was judged before the tribunal of nascent Arab nationalism."12

Although there is a renewed interest in the Ottoman history of the Great War and much of the new historiography uses memoirs, there is hardly any writing on the memoir literature that can be called content analysis. ${ }^{13}$ On the Turkish side, until recently the prevalent discourse has been what I will refer to as the "stab in the back syndrome" whereby the Arabs are seen as seditious traitors who collaborated with the enemy to bring down the Empire. This resulted in an entire generation of political actors in the young Turkish Republic whose attitude to the loss of the Arab provinces can be summed up as "good riddance." Particularly in the years after the abolition of the Caliphate in 1924 the theme of "Arab treason" became the dominant narrative and was featured as such in school textbooks:

... The descendant of the Prophet Sharif Husain ... chose to accept the gold of the enemy. . . . and exchanged the honor of Islam for a Kingdom under the protection of the English. He actually entered into competition with the

11 Falih Rıfkı Atay, Zeytindağı (Istanbul: Pozitif Press, 1932), 91-92. The word he uses is "Visrua" which is actually not a Turkish word. A German officer was to refer to him as "Vizekönig," see Talha Çiçek, War and State Formation in Syria: Cemal Pasha's Governorate During World War I 1914-1917 (London: Routledge, 2014), 3. This an excellent book that combines European and Ottoman sources and should be considered the most current work on this topic. As such it has been used extensively in this study. See also Ali Fuad Erden, Birinci Dünya Savaşında Suriye Hatıraları [Syrian Memoirs during the First World War] (Istanbul: Iş Bankası, 2003), 95: "Everyone feared Cemal Pasha...."

12 Youssef Mouwad, "Jamal Pacha, en Une Version Libanaise: l'Usage Positif d'une Legende Noire." In The First World War as Remembered in the Countries of the Eastern Mediterranean, ed. Olaf Farschid, Manfed Kropp, Stephan Dahne (Beirut: Orient Institut, 2006), 425-446.

13 For a recent useful overview of the historiography see, Ömer Turan, "Turkish Historiography of the First World War," Middle East Critique 23, no. 2 (2014): 241-257. 
enemies of Islam for the shedding of the pure Turkish blood, with the desert and town Arabs in his train.... ${ }^{14}$

The early republican press frequently referred to Islam as "an Arab religion." Mustafa Kemal endorsed the publication of a treatise entitled, There is no Religion, Just Nationality: My Turkishness is my Religion. ${ }^{15}$ Thus Arabs became in a very real sense the "essential other" for the nascent Turkish Republic:

In order to fortify Turkishness as the basic historical consciousness of the new citizen, the "traitorous Arabs" who had "stabbed the Turks in the back" became the ideological cement for the new radical westernizing ideology. ${ }^{16}$

This mindset is reflected in four of the five memoirs used in this volume. Falih Rifk 1 with his scathing irony about how "foreign" the Arab lands were for Turks, Ali Fuad with his firm conviction that the "Arab officers were planning to poison the Turks in their sleep," Naci Kıcıman with his frequent references to "barelegged Arabs who were spilling the blood of Anatolian lads," and finally Münevver Ayaşl1, who treats the population of Beirut very like a British memsahib would have treated Indian subjects of the British raj, are all imbued with some aspect or other of the mentality described above. The one exception is Hüseyin Kazım, who places the blame for the loss of Arab lands squarely on the shoulders of corrupt and incompetent Ottoman officials.

The five memoirs used in this book were each chosen for a specific purpose. Falih Rifkı was Cemal Pasha's close aid and an eyewitness to his policies in the region. Moreover, he also represents a typical example of the post-imperial Turkish mindset regarding the Ottoman past. From his texts, I chose Zeytindağ $ı$ in particular because it is beautifully written, and is therefore a pleasure to translate.

Ali Fuad was Cemal's "nuts and bolts man" who actually administered the Fourth Army zone. His memoir was chosen because Ali Fuad was an

14 Talha Çiçek, "Erken Cumhuriyet Dönemi Ders Kitapları Çerçevesinde Türk Ulus Kimliği Inşası ve 'Arap Ihaneti”' [The Construction of Turkish National Identity in the Light of Early Republican School Textbooks and "Arab treason"], Divan 17 (2012): 169-188. Çiçek is quoting a school history textbook from 1931.

15 Şükrü Hanioğlu, Ataturk: An Intellectual Biography (Princeton: Princeton University Press, 2011), 63. The work in question is Ruşeni Barkın, Din Yok Milliyet Var: Benim Dinim, Benim Türklüğümdür.

16 Çiçek, "Erken Cumhuriyet," 181 
atypical example of a Turkish officer of the time: he was a hard-headed realist and a dreamer who likened himself to the legendary figure of the French Revolution, Saint-Just.

Hüseyin Kazım appears in these pages because he was an exceptional character. A member of the Ottoman elite, the son of a legendary long-term governor of Trabzon, and a founder member of the CUP who fell out with his erstwhile comrades. He was also exceptional in that he was the only one of the five who abstained from taking an active part in the politics of the republican era.

Naci Kiciman's memoir was chosen because it is both a memoir and a biography. The memoir is as much about Naci Kicıman himself as it is about his legendary commander, Fahreddin Pasha, the defender of Medina. It is also a typical example of the "stab in the back syndrome," which will be explained below.

I chose Münevver Ayaşlı because of the fact that her memoir is one of the very few eyewitness accounts of the last days of the Turks in Syria written by a woman. Furthermore, her memoirs were written decades after the events and yet represent a remarkable feat of memory judging by their impressive accuracy.

The memoirs that I have used fall into the category of what Philipp Wirtz refers to in his insightful book as "post-Ottoman memoirs," given the fact that they were all written and published in the context of Kemalist Turkey. As he points out, memoir writers often wrote as a result of the urge to "bear witness," or "to set the record straight."17

\section{Some comments on the use of memoirs and the concept of "collective memory"}

There is an extensive literature on autobiography, describing its impact on the structure of collective memory and its contribution to the formation of collective identity. ${ }^{18}$ It would be beyond the scope of this study to attempt

17 Philipp Wirtz, Depicting the Ottoman Empire in Turkish Autobiographies. Images of Past World (New York: Routledge, 2017), 23, 33.

18 David Middleton and Derek Edwards, eds., Collective Remembering: Inquiries in Social Construction (London: Sage Publications, 1990); Dorthe Bernsten and David C. Rubin, eds., Understanding Autobiographical Memory. Theories and Approaches (Cambridge: Cambridge University Press, 2012); James W. Pennebaker, Dario Paez, Bernard Rime, eds., Collective Memory of Political Events (New Jersey: Mahwah, 1997); Paul Connerton, "Seven Types of Forgetting," Memory Studies 1, no. 1 (2008): 59-71; Robin Ostle, 
an exhaustive theoretical treatment of the subject. I will limit myself to a few very brief observations that will have a direct bearing on the memoirs discussed here. In the words of the pioneering doyen of collective memory studies Maurice Halbwachs:

Collective memory differs from history in at least two respects. It is a current of continuous thought whose continuity is not at all artificial for it retains from the past only what still lives or is capable of living in the consciousness of the groups keeping the memory alive. . . It provides the group a selfportrait that unfolds through time, since it is an image of the past, and allows the group to recognize itself through the total succession of images. ${ }^{19}$

The memoirs studied here are indeed a very good reflection of the "self-portrait" of the late Ottoman personages and their "images of the past."

Memoirs as a historical source for the last years of the "atrak" in the Arab lands are indeed indispensable, with the proviso that they be used without any illusions as to their "objectivity." Memoirs are by their very nature subjective, and demand, in the words of one of major thinkers of the subject, some form of "autobiographical pact" between the author and the reader whereby the reader will be free to "look for differences (errors, deformations etc.)" with the historical record. ${ }^{20}$

Everyone thought they were making history or at the very least providing testimony for future generations. In a recent study on genocide denial in Turkey, Müge Göçek notes: "The main limitation of memoirs as a historical source is that it is hard to move beyond the personal idiosyncrasies of individuals in general and their political orientation in particular." ${ }^{21}$ Yet it is precisely those "idiosyncrasies" and "political orientations" that are my concern here.

As Philip Dwyer has pointed out, the actual act of writing down what is remembered can transform what was in fact a subjective impression into a "historical reality." "In this manner, memoirists become mythmakers,

Ed de Moor, and Stefan Wild, eds., Writing the Self: Autobiographical Writing in Modern Arabic Literature (London: Saqi Books, 1998).

19 Maurice Halbwachs, excerpt from "The Collective Memory," in The Collective Memory Reader, ed. Jeffrey K. Olick et al. (Oxford: Oxford University Press, 2011), 139-155.

20 Philippe Lejeune, Le Pacte Autobiographique, accessed January 12, 2017, www. edisciplinas.usp.br/pluginfile.php/1896026/mod_resource/content/1/lejeune_pacte autobiographique-pacte_1.pdf.

21 Müge Göçek, Denial of Violence: Ottoman Past, Turkish Present, and Collective Violence Against the Armenians 1789-2009 (Oxford: Oxford University Press, 2015), 54. 
creating records that not only influence the manner in which readers see the past, but also how historians interpret the past." All five of the memoirists in this volume were very self-consciously writing for posterity. All five texts to be cited here were, again to echo Dwyer, "remembered, restructured, and filtered by time." As he points out, what the writers of the memoirs think is worth remembering shapes the "cultural memory" of the future. The writers of the memoirs used in the present volume are very much a product of the "cultural memory" of the Kemalist state. ${ }^{22}$

All five memoirs analyzed in this book have a political agenda. Some memoirs are indeed in self-conscious dialogue with one another. Hüseyin Kazım specifically states that he wrote in order to "expose the lies of Cemal Pasha." It is important to know when the memoirs were written, and the historical context in which they were published. All memoirs also have a projected public, an audience for whom they are intended.

Falih Rifkı's Zeytindağ 1 was first published in 1932. Meanwhile, Falih Rifkı had taken the surname Atay and gone on to write books and articles of a panegyric nature lauding Atatürk as a godlike leader. Zeytindağg, therefore, is very much a product of an early republican mindset which saw separation from the Arab lands as a blessing. Falih Rufkı was very close to the Cemal Pasha and was an eyewitness to some of the period's key events. Yet, Rufk 1 is extremely cynical regarding what he calls "Ottoman Imperialism." Rifkı refers to Enver in extremely negative terms as an "empty head covered in pomaded skin" yet always refers to Cemal with the utmost (if sometimes somewhat grudging) respect, reflecting the various cliques and clientele networks that had evolved around the Enver-Talat-Cemal triumvirate. The Palestine front was the last stand of the Ottomans in the Arab lands. The critical battles waged between the Ottomans and the British in this area were to mark the collective memories of the last generation of Ottomans.

The political climate at the time of the memoirs' publication is also significant. For example, although Falih Rifkı fitted in fine with the air de temps in the heyday or Kemalism, it is no wonder that Hüseyin Kazım's memoirs were published only after his death in 1934, given the unabashed anti-Kemalism of the writer. Hüseyin Kazım is an exceptional figure in many ways. Firstly, unlike almost all the civilian and military officials on the Palestine-Syria front, he did not join the nationalists in Ankara, nor did he go on to hold prominent

22 Philip Dwyer, "Making Sense of the Muddle: War Memoirs and the Culture of Remembering," in War Stories. The War Memoir in History and Literature, ed. Philip Dwyer (New York: Bergahn, 2017), 1-27. 
positions in the new Turkish state. After returning from Beirut, he became a member of the penultimate Ottoman parliament when he was an MP for the province of Aydin. In 1920, he was elected to the post of Deputy Speaker. In 1921 he was part of the Istanbul government's official delegation in the Bilecik negotiations that attempted to find some middle ground between Istanbul and the nationalists in Ankara. The negotiations failed and the Istanbul delegation was "invited" to come to Ankara. Hüseyin Kazım recounts feeling that he was treated as a hostage. In fact, he was very critical of Mustafa Kemal and the new regime, going so far as to state in his memoirs that Kemal created "a new form of oppression and despotism called the republic." ${ }^{23} \mathrm{He}$ wrote two versions of his memoirs, one that ends in 1929 and another, ending in 1930. The second text was written specifically to answer accusations against its author. He openly refers to Mustafa Kemal's epic speech, the Nutuk, where Kazım was, as he states, falsely accused of being a defender of the sultanate. His self-defense is scathing, going so far as to refer to the iconic text as "a masterpiece of lies and distortion" (şah-eser-i kezb-u tahrif). It is therefore no wonder that his memoirs were only published after his death in $1934 .{ }^{24}$

Ali Fuad [Erden] states in the introduction to his memoirs that he "waited forty years which is two generations" before publishing his writing. He was clearly concerned about protecting the name of Cemal and others who were involved in the last days of Ottoman rule in Syria. He clearly states that "Cemal Pasha was my Commander and will always be my Commander." ${ }^{25}$ Münevver Ayaşlı was writing some forty years after

23 Hüseyin Kazım Kadri, Meşrutiyettden Cumhuriyete Hatıralarım [My Memoirs from the Constitutional Period to the Republic], ed. Ismail Kara. (Istanbul: Dergah, 2000), 123.

24 Ibid., 190, 223. In 1927, Mustafa Kemal delivered a mammoth five-day parliament speech, the Nutuk (October 15-20), which amounted to an apologia of everything dealing with the founding of the republic. In this speech there are three negative references to Hüseyin Kazım. See footnote 35 by the editor, Ismail Kara. For one of the rare critical evaluations of Nutuk see Hülya Adak, "National Myths and Self Narrations: Mustafa Kemal's Nutuk and Halide Edib's memories and the Turkish Ordeal," South Atlantic Monthly 102, nos. 2/3 (2003): 509-528.

The memoirs of Kazim Karabekir, one the leading commanders of the Anatolian resistance and an opponent of what he saw as Kemal's dictatorial inclinations, were in large part a rebuttal of the Nutuk, to the point where one prominent late-Ottomanist called it the "anti-Nutuk." See Erik Jan Zürcher, "Young Turk Memoirs as a Historical Source: Kazim Karabekir's 'Istiklal Harbimiz,” Middle Eastern Studies 22, no. 4 (1986): 562-570.

25 Philipp Wirtz, Depicting the Late Ottoman Empire in Turkish Autobiographies, 22-34. Wirtz rightly points out the importance of "forewords" or "introductions" as key to understanding the context of a late Ottoman memoirs. 
the events she described and thus her text is very much imbued with the conservative world view of a first-generation republican woman. Her somewhat facile snobbery is interesting as she makes her judgments less along ethnic lines but focuses more on class. Thus, the Lebanese merchants are "unctuous and toadying" while the Sursocks are very "convenable" (kibar) and it is a sign of her family's social standing that Linda Sursock "would come for coffee" at Ayaşli's home.

I have used the memoirs as sources for a study of intellectual, not military, history. In this regard (particularly in relation to the memoirs of Kicıman and Erden), I have not translated large tracts of detailed military operations. I am more interested in passages that illustrate the mindset of the actors involved. Also, there is much repetition which I have chosen to omit.

Another point that needs clarification is the manner in which I have handled the actual process of translation itself. Jay Winter refers to the ways in which Henri Barbusse's novel Le Feu (1916) was "sanitized" in its English translation in 1917, where references to soldiers as "victims and executioners" was softened because "language codes precluded direct translation and silenced the difficult moral judgement. ..."26 I have tried to avoid euphemistic censorship and sensationalism while striving to give the actual "flavor" of the Turkish original.

\section{Turks and Arabs: an uncomfortable symbiosis}

In the memoirs covered for this book, I came across a contradictory worldview regarding the Arabs and Arab lands in the memoirs of Ottoman individuals who were in the Arab region during the last years of the Empire. The contradiction lies in the constant reference to the "loss" of the Arab lands, yet they all express a deep sense of alienation and an ever present feeling of "them" and "us." Yet the "us," although essentially meaning Turks, remains ambivalent, sometimes including the Muslim Arabs and even the Christians.

Halil Halid Bey was one of the staunchest defenders of Turkish-Arab brotherhood, waxing lyrical about the special relationship between the two races and declaring that

26 Jay Winter, "War Memoirs, Witnessing and Silence," in Dwyer, War Stories, 27-47. 
... the Arab and the Turk cannot live without each other. ... The Arab race was a like a diamond that had been broken and scattered into a thousand pieces. It was the Turks who first realized how valuable they would be if united. After they became united as brothers in religion they came to the Arab lands and helped unite all the pieces. Verily, the crown of the Turkish sultanate was emblazoned and glowed with the brilliance of all these pieces of the diamond that was united. ${ }^{27}$

There is a very clear idea of the "otherness" of the Arabs, which is sometimes expressed in downright racist stereotyping. For example, Falih Rifk1 uses the phrase "hair of the Arab" (Arap saçı) meaning "to make something tangled and confused." ${ }^{28}$ Rufki's disparaging references to the Arabs of Medina who had made a vocation out of exploiting pilgrims, and his conviction that Istanbul was the true Muslim city that had made worship into an art form, are very similar to the language one hears today from Turkish hajis returning from pilgrimage. When Zeytindağ $l$ was written, Turkey was firmly looking west and the "Orient" was a thing of the past. In subsequent editions of Zeytindağı, Rufkı's attitude would become even more severe: "Ottoman history has been a world of lies. Lying is not shameful in the Orient." ${ }^{29}$ Evidently, by the time he wrote and published Zeytindağt, Falih Rifkı had moved much closer to the official line of Turkish Kemalist nationalism.

Yet, some Ottoman officials had a very self-critical view of the Turkish presence in Arab lands. Hüseyin Kazım was a very distinguished example. While he served as the Vali (Governor) of Aleppo, Kazım observed that the Ottoman officials collaborated with the local notables to create an alliance of "mutual interest" in order to exploit the local population. In Aleppo Kazım became something of a local celebrity. Appointed as Vali in 1910, he became the nexus of what can be called the "Hüseyin Kazım Affair." Seen by the emerging liberal middle class of Aleppo as the new reformist Vali

27 Çerkesşeyhi Zade Halil Halid, Türk ve Arap [The Turk and the Arab] (Cairo: n.p., 1912, reprinted edition, Istanbul: Melissa Press, 2016), 61-62. Halil Halid was an interesting figure. After teaching Turkish to British diplomats at Cambridge for over ten years, he became a devoted propagandist for the Young Turk regime. He later served as the Ottoman Consul in Bombay.

28 See below, p. 12.

29 Falih Rıfkı Atay, Zeytindağı, online edition, accessed March 11, 2017, www.kitapsevenler. com, 7-8. 
replacing Fahreddin Pasha, an Ottoman military man of the old school, Kazım came to be known as "our Vali / Walina."

Unusually for an Ottoman official, he spoke fluent Arabic. On the occasion of his triumphant return from Istanbul, where he had gone to defend his reformist policies,

A large crowd greeted him at the train station. Troops in formation and a band made up of the students from the College de La Terre Sainte serenaded his arrival. Refusing to board a carriage, Hüseyin Kazım walked to the governorate building with the procession stopping to deliver two speeches on the way. ${ }^{30}$

There followed a flurry of telegrams to and fro between Aleppo and Istanbul, with which the traditional notables of the city did their best to assure his downfall. They ultimately succeeded and he has recalled in 1911. In a letter to a friend shortly before his recall Kazım stated the following:

... As far as I can see the government made two big mistakes here. Firstly it did nothing to confirm its existence, and secondly it did not even think about pleasing the people. ... Since I have been here I have tried to win over the people. .. . I think that to a certain extent I have succeeded in making them more hopeful towards the state. Now everyone has understood that there is a government that defends the weak, is in favor of justice, and is trying to heal old wounds. ${ }^{31}$

Yet, even with Hüseyin Kazım there is an undertone of a belief in his entitlement to rule. With reference to Cemal Pasha's oppressive rule in Syria, Kazım states on at least two occasions in his memoirs that it was because of Cemal Pasha's cruelty that Syria was "lost." 32

It is difficult to know what to make of the episode in his memoirs where he recounts how he was approached by some Beirutis who declared that they were prepared to go to Jerusalem to tell General Allenby that "they wanted to remain under Ottoman rule." There is no mention in any literary source

30 Keith David Watenpaugh, Being Modern in the Middle East: Revolution, Nationalism, Colonialism and the Arab Middle Class (Princeton: Princeton University Press, 2006), 110. We will meet Fahreddin Pasha below in the section on the siege of Medina.

31 Ismail Kara, "Halep'den Mektup Var" [There is a letter from Aleppo], Derin Tarih (January 2017): 3-6.

32 Hüseyin Kazım Kadri, Meşrutiyettden Cumhuriyete Hatıralarım, 139, 143. 
of such a proposal. On the other hand, Kazım is not given to invention; if anything, his memoirs are somewhat given to understatement. ${ }^{33}$

Hüseyin Kazım's most remarkable achievement was his idea to compile an encyclopedic work, Lubnan: Mubahis Ilmiyya wa Ijtimaiyya (Lebanon: Scientific and Social Research), published in August 1918 and prepared under the protection of the Mutasarrif Ismail Hakkı Bey, probably at the instigation of Hüseyin Kazım who had very close relations with him. ${ }^{34}$ This multi-authored work, comprising articles by Arab, American, and Turkish authors, stands as an enigmatic piece of scientific compilation of knowledge concerning a very broad spectrum of subjects. People, geography, religions, agriculture, and monuments are all covered in twenty chapters. The editor and author of two of the articles was Father Louis Sheikho, a Jesuit priest with no reason to love the Turks, as he and his order had been the target of systematic harassment by Cemal Pasha and Azmi Bey, the Vali of Beirut, who deeply distrusted the Jesuits as a result of their well-known pro-French leanings. ${ }^{35}$

The enigma that surrounds the work lies in its timing. The volume was approved by Cemal at the end of 1917 when Baghdad and Jerusalem had already fallen (March 11 and December 9) and published in August 1918, literally weeks before the Allied occupation of Beirut. What was the aim of such a work? Carla Eddés hypothesis regarding this issue is as follows:

This body of knowledge was nothing other than a continuation of the war by other means, even if these means had to be adapted to the changing conjectures of war for the main protagonists. [They] were the Ottoman officials, and the local actors' ideologies of the Town [Beirut] and the Mountain with all their permeability and nuances. ${ }^{36}$

33 Ibid., 142-143.

34 Carla Eddé, "Le Savoir Encyclopedique ou la Continuation de la Guerre par d'Autres Moyens," paper presented at the symposium La Première Guerre Mondiale au Proche Orient: Experiences, Saviors, Memoires, Université St. Joseph, Beirut, November 3-4, 2014. Quoted with the permission of the author. The work was in Arabic and Turkish.

35 Christian Tautel and Pierre Wittouck S. J., eds., Le Peuple Libanais dans La Tourmente de la Grande Guerre 1914-1918 d'après les Archives des Peres Jésuites au Liban (Beirut: Presses Universitaire St. Joseph, 2015), 63. A diary entry by Father Shiekho for February 2, 1917 reads: "The Turks, if they are victorious, are determined to crush the Christians in their empire. They are prepared to use any means necessary to re-establish their wounded authority in Syria and Arabia. Cemal Pasha is travelling the country and striving to revive Muslim fanaticism."

36 Eddé, "Le savoir encyclopedique." 
It is likely that Hüseyin Kazım served as the go-between in linking Sheiko and Father Antoine Salhani, another Jesuit, with Azmi Bey and Ismail Hakkı Bey. ${ }^{37}$ Kazım, apart from writing the Preface, contributed two articles to this gargantuan task by writing both "Islam" and (as he was a trained agronomist) "A scientific overview of agriculture."

Were the Ottomans hoping that they would be able to keep Lebanon as part of the Empire after the peace treaty? Was the volume intended as a document for posterity? Was it intended to serve as a blueprint for a future independent state of Lebanon? Eddés hypothesis regarding the issue is that " $t$ ] his encyclopedic work turned out to be a work of propaganda for both the Ottoman Empire and the specific identity of Lebanon."38

It is also a very important document that is very evocative of what I have referred to above as the "uncomfortable symbiosis": an Ottoman Turkish former governor, who has chosen a life of contemplation and retreat in Lebanon, befriends a circle of Jesuit fathers, who have been harshly victimized by his own government, and convinces them to contribute to an encyclopedic work on a land that will soon be "lost" to the Turks. Hüseyin Kazım stated in the Preface to the volume:

The government of Lebanon, in publishing this work, brings Lebanon to the attention of the world and exposes to the world the magnificent scenery that is typical of this Mountain, blessed with beautiful flora and fauna. The aim [of the government] can be summed up briefly as twofold, to know itself and to make itself known. This was a plan that was neglected until now. The government of Lebanon wanted to see with its own eyes the regions of this

37 Eddé, "Le savoir encyclopedique"; Henri Jalabert S. J., Jesuites au Proche-Orient Notices biographiques (Beirut: Université de Saint Joseph, Faculté des Lettres et Sciences Humaines, 1987), 168-69, 210-211. As Jalabert describes, "Pere Louis Sheikho (1859-1927): When the war of 1914 led to the expulsion of the Jesuits from the University [St. Joseph], his services to the entire culture of the Orient earned him, with the friendship of an important member of the Young Turk Party, former Vali of Aleppo, Hüseyin Kazım Bey, the right to work in the Bibliotheque Orientale which was thus saved from pillage and ruin, together with the famous remark [about him] by Cemal Pasha during the bloody trials of the military tribunal, 'He is the Sultan of the Arabic language." Antoine Salhani (1847-1941) was also an accomplished Arabist. The articles contributed by Sheikho were entitled, "Lebanese People and their Religious Affiliations. A Brief Account of Lebanese History from antiquity to the Arab Period." He also contributed an article on Beirut. Both Sheikho and Salhani rejected a draft article on foreign schools because it contained anti-French remarks, see Eddé, "Le savoir encyclopedique."

38 Eddé, "Le Savoir Encyclopedique." 
land, splendid and historic, and then to care for them with all of its heart. That is what caused it to prepare this book. ... Generally speaking, this book comprises all the studies which will find favor with all the Lebanese of all walks of life. ${ }^{39}$

With these words Hüseyin Kazım was elegantly summarizing the symbiotic feeling of not really belonging, yet belonging very much. Why would a government that was about to abandon Lebanon publish a multi-authored volume, prepared in record time? Perhaps, as put by Kazım himself, "to know itself and to make itself known." 40 The alternative explanation may have been that even in the last months of the war they expected to be at Germany's side during the peace negotiations. This will be discussed in the last section of this introduction.

\section{Turkish attitudes towards Arab soldiers in the 0ttoman armed forces as reflected in the memoirs}

According to Mehmet Beşikçi, whose book remains a leading reference point on the issue of Ottoman military mobilization in the Great War, statistics regarding the proportion of Arab troops in the Ottoman forces are"fragmentary." In the Ylldırım Army Group, formed in the last year of the war, the deputy chief of staff noted in a report that $66 \%$ of the troops were Turkish and 26\% were Arab. In his evaluation of the proportion of Arabs in the Ottoman forces, Beşikçi extrapolates from the general proportion of the population of each ethnic group in the Empire to their proportions in the armed forces: "out of about totally 23 million people in 1914, the approximate ratios of major groups would be as follows: 47 percent Turks and Anatolian Muslims, 37 percent Arabs, 8 percent Ottoman Greeks, 7 percent Armenians and 1 percent Jews." ${ }^{41}$

Arab troops were sent to distant fronts such as Gallipoli and Eastern Anatolia. Yet, the attitude of the Ottoman high command toward Arab

39 Lubnan, Preface (Dibaje). Yet it is interesting that there is no mention of the volume in his memoirs.

40 Ibid. Ismail Kara, who edited his memoirs, claims that "[after] the armistice in 1918 when the Ottoman state lost Syria, he refused the position of Vali of Beirut which was offered to him by the locals and returned to Istanbul." Meşrutiyettden Cumhuriyete Hattralarim, 24. This is not mentioned in the memoirs.

41 Mehmet Beşikçi, The Ottoman Mobilization of Manpower in the First World War: Between Voluntarism and Resistance (Leiden: Brill, 2012), 253. 
troops was often disparaging. A recent official publication from the Turkish General Staff Military History Department declares:

The Turk who by nature possesses many of the military virtues, is perfect, brave, undemanding, dauntless, obedient, submissive and genuinely loyal. As for the Arab, he is far from being this valuable. Arab troops never carried out, were unable to carry out, the duty expected of them. . . From the point of view of purity, loyalty, determination, readiness to sacrifice their lives, resilience and courage they were inferior to the Turks. The nucleus of the Turkish army was made up of heroic children of the Anatolian plateau. . . The Muslim Arab units were not suited to the needs of warfare, either defensive or offensive. For this reason, all Arab units needed to be reinforced by Turkish units in a proportion of $1 / 3{ }^{42}$

General Liman von Sanders, commander in chief of the Palestine front, had a more moderate view as to the relative capacities of Turkish and Arab soldiers:

The Turkish soldier, particularly the Anatolian, is excellent fighting material. Well looked after and sufficiently nourished, properly trained and calmly led these men will accomplish the highest aims. A large part of the Arabs may be made into good usable soldiers, if from the very beginning of their service they are treated with strictness and justice. ${ }^{43}$

Thus, even in the German general's estimation, the difference between Turkish and Arab soldiers was patent.

Regarding the military units in the Fourth Army district, the official military record notes that in January 1917, the Fourth Army Command had asked for "10,000 reinforcement troops of Turkish blood" (Türk soylu ikmal eri). In Mount Lebanon, it was stated, "[i]n the 43rd Division in Mount Lebanon the battalions were made up of 670 soldiers. They were all Arabs from the zone of Beirut." ${ }^{44}$ These records amount to an official account of

42 Birinci Dünya Harbinde Türk Harbi, IV. Cilt., 1. Kısım., Sina Filistin Cephesi, Askeri Tarih ve Stratejik Etüt Başkanlığı [The Turkish War in the First World War, vol. IV, part 1: The Sinai and Palestine Fronts, Directorate of Military History and Strategic Studies] (Ankara: Genelkurmay Başkanlığı Harp Tarihi Dairesi, 1979), 336.

43 Liman von Sanders, Five Years in Turkey (Annapolis: United States Naval Institute, 1927), 191. "Liman Pasha" served for five years as the head of the German military mission in the Ottoman Empire.

44 Birinci Dünya Harbinde Türk Harbi, 483-484. The official military history gives the proportion of Arab troops in all units. 
the military collective memory of World War I. All statements about the Arab troops, such as the above, are anonymous, but they are footnoted with references to the documents in the official archives of the Directorate of Military History and Strategic Studies (ATASE).

Another curious feature of these volumes is their similarity to the memoirs of Ali Fuad cited below. Regarding the situation of the Fourth Army, the records state:

The GHQ was in a very critical situation, it was like a buoy floating in a sea of rebellion. ... In the summer of 1915 nearly all its effectives had been sent to other fronts. All that was left in Syria was the 23rd Division and the coast guard. All of them were Arabs. Most of their officers were Arabs. ... Propaganda was rife among the Arab officers and it was heard that the Turkish officers were to be killed one by one in the night and the revolutionary committees would take over, declare the independence of Syria, and join with the French. ${ }^{45}$

The image of a "buoy floating in a sea of rebellion," and the Turkish officers murdered in their sleep is an almost verbatim repetition of Ali Fuad's memoirs. ${ }^{46}$ It is highly likely that the anonymous retired officers who compiled these volumes used contemporary memoirs like those of Ali Fuad and Cemal Pasha in their work.

While the surrender of the British forces under General Townsend was being negotiated in Kut in Mesopotamia in April 1916, the Ottoman General Halil Pasha stated that in the matter of the exchange of prisoners, "he would insist on exchanging Britons for Turks, Indians for Arabs." ${ }^{47}$ Evidently the Turkish commander had the same racial sliding scale in mind as the British.

Many of the soldiers of the famed 19th Division in Gallipoli who were "ordered to die" by Mustafa Kemal were Arabs. Together with their Turkish counterparts, they stemmed the critical Anzac offensive on April 25, 1915. Most of them did die. It is interesting that in the preface of Edward J. Erikson's famous book, we meet the same mindset seen above:

45 Ibid., 692.

46 See below, p. 98.

47 Neil Faulkner, Lawrence of Arabia's War. The Arabs, The British, and the Remaking of the Middle East in WWI (New Haven, CT: Yale University Press, 2016), 93. 
This book is about the Turkish Army, although it carries the title A History of the Ottoman Army in the First World War.... Although it is true that ... many of the subject peoples, such as Kurds and Arabs, served in the army, the essence of the Army was Turkish.... That is why, in this book, the term Turkish Army is used instead of the more proper term Ottoman Army. ... ${ }^{48}$

On February 25 Lieutenant Colonel Mustafa Kemal telephoned divisional headquarters and declared:

Please Sir, we must ask [a favor] from the Commander Pasha [The Minister of War, Enver Pasha]: The regiments numbered 72 and 77 that were given under my command are all Arabs.... Some of them are Yezidi and Nusayri, who are against the war. Their [military] training is also limited. Let them take these [regiments] back and return my two previous regiments that were composed of genuinely Turkish boys (halis Türk delikanlıları). ${ }^{49}$

The request was refused and the 77th Regiment lost 700 men (nearly its entire force) in the first day of battle.

In October 1915, Cemal Pasha, partly to combat the ill will engendered by the executions of the Arab patriots in Beirut, arranged for a goodwill tour for some thirty prominent Arab intellectuals from Syria. The aim was to show Arab-Turkish solidarity in the war effort. Mustafa Kemal took impish pleasure in exposing this delegation of Syrian literati to enemy fire during a visit to their Arab brethren in the trenches. His aide wrote with glee how

[the] dignitaries in the group became alarmed and panicked as a result of violent explosions, followed by the whistling sound of shrapnel flying through the air. Immediately they turned pale. Instinctively they looked to their horses.... When they pronounced the word yallah [let's go!], the second wave of bombardment had already started, and this time the shrapnel was coming pretty close. It was looking for the man whose number was up. . . . After our guests left, my commander [Mustafa Kemal] had a good laugh

48 Edward J. Erikson, Ordered to Die: A History of the Ottoman Army in the First World War (Connecticut: Greenwood Press, 2001), xvi.

49 Ayhan Aktar, "A propaganda tour organized by Djemal Pasha: The Arab literati's visit to the Gallipoli Front, 18-23 October 1915," in Syria in World War I: Politics, Economy, and Society, ed. Talha Çiçek (New York: Routledge, 2016), 61-86. 
when I described to him how the code-word yallah had an accelerating effect on them. ${ }^{50}$

It is remarkable that the same disparaging superiority is seen in the memoirs of Falih Rıfkı, Naci Kıcıman, and Ali Fuad, which will be discussed below.

There is at least one memoir written by an Arab officer in the Ottoman army that gives the lie to the image of "Arab unreliability" or "Arab cowardice." Abdallah Dabbous was from a well-to-do Beiruti family and fought as an NCO in a machine gun unit in the Ottoman forces. ${ }^{51}$ In the battles for Amman in March-April 1918 he took part in a critical fight in the village of Shunet Nimrin. He would have been part of the Ottoman 48th Division under the command of Colonel Iskender Bey who defended the village from April 30 to May $4 .{ }^{52}$ Dabbous gives a very cool headed account of the engagement, where the hill of Nimrine changed hands several times:

We received the order to go back to our initial position the hill of Nimrine.

During the afternoon our enemies started to show up, one thousand men on their horses. Here we recognized that we are not more than victims and that our end had come. When the troops approached we opened fire. This situation continued until sunset. The commander ordered us to retreat and stop firing. ${ }^{53}$

Dabbous's unit then took part in the final days of the retreat towards Deraa during which they camped at a village called Ramla, some two hours from Deraa, where they were surrounded by the enemy:

The luckiest troops made their way to Deraa but our troop met with the Australian army on the way. We made for the sand hills above the village and began to open fire. The enemy successfully surrounded us and we became like a point in a circle. We were out of bullets and 40 men were killed, so it was useless to stay and continue the fight. I gave the order to pull back and we regrouped in the square of the village. We were almost 200 soldiers. I told

50 Ibid.

51 Abdallah Dabbous, Muzakkerat Abdallah Dabbous [The Memoirs of Abdallah Dabbous] (Beirut: n.p., 1993). My thanks to his great-granddaughter, Sara Itani, for bringing this source to my attention. My thanks also to Sara Itani and Theresa Mikhael for the translation of the passages cited here.

52 Faulkner, Lawrence of Arabia's War, 396.

53 Dabbous, Muzakkerat Abdallah Dabbous, 135. This would have been the New Zealand Mounted Rifles. See also Faulkner, Lawrence of Arabia's War, 395. 
the officers to come and told them that we faced a danger worse than the foreigners. Those Bedouin look at you with hatred and they are waiting for you to show weakness so they can start their extermination. ${ }^{54}$

As most of his superior officers were either killed or wounded, Dabbous was put in charge of what was left of his unit. When they were surrounded by Bedouin, Dabbous ordered his troops to mount the machine gun and fire over the enemy's heads. He then called out to them,

"You the Arabs! I am going to give you one minute to leave and go back to your homes." Here I ordered the soldiers to start firing over their heads. The Bedouin were so afraid that they ran to their homes. The soldiers started celebrating. ${ }^{55}$

Nonetheless, Dabbous and his superiors eventually decided to surrender and met up with the British cavalry:

Two horsemen began to approach us slowly, and when they were fifty meters from us they signaled us to put our guns down. As they came up I told them I could speak English so they felt safe and we continued on our way. ${ }^{56}$

Eventually, after Dabbous and his men were taken prisoner, he was summoned to the tent of the commanding officer:

I entered a luxurious tent where you can find newspapers, a radio, a telephone. . . . The officer [asked me], "Are you the officer of these nonunified troops?" I replied, "No, I am not, I am the leader of a machine gun company, and the commander of these troops is in the building beside us and we do not know if he is going to live or if he is going to die. He said, "What brought you here so you have caused the death of 40 of your soldiers and 40 of ours? If you had surrendered, you would have saved them." I said, "I am an Arab and a soldier in the Ottoman army, and as an Ottoman I am doing my duty like the Turks and the rest of the population." He said, "Would this prevent you from joining the Arab Army? I think they need a man like you who is fluent in English and also an experienced machine gunner."

54 Dabbous, Muzakkerat Abdallah Dabbous, 136-137. His account is accurate as the Turks definitely preferred to surrender to the British rather than Arabs. See also Faulkner, Lawrence of Arabia's War, 446.

55 Dabbous, Muzakkerat Abdallah Dabbous, 138.

56 Ibid., 139. 
I said, "No Sir, I cannot fight against the Ottomans after a long and harsh time fighting for them." 57

In fact, very few Arab officers defected to the British or the Sharifian forces. The majority remained loyal to the end, serving with distinction on various fronts. This was due to "a mix of professionalism, camaraderie, suspicion of British and French intentions, lack of confidence in the opportunistic leadership of the Arab Revolt, and antipathy towards its feudal-tribal social base and reactionary program." ${ }^{58}$ The initial British effort, soon after the outbreak of the Arab Revolt, to "turn" Arab Ottoman prisoners of war, officers and enlisted men, was a complete failure. On August 1, 1916 the first group of prisoners brought from India arrived in Jeddah. Upon their arrival they refused to get off the ship stating that they would not fight against the Turks. They were sent back to Egypt. Reginald Wingate, the Governor General of the Sudan referred to the episode as a "fiasco." A few months later, in November, the British had to force Ottoman prisoners on board ship at Bombay at bayonet point. However, later in the war a core of ex-Ottoman Arabs would join the Arab Army. ${ }^{59}$ Some, like the key commander Jafar Al Askari, would have a critical role in training Arabs as regular troops. ${ }^{60} \mathrm{Al}$ Askari was taken prisoner by the British in 1916 and after he decided to join the Sharifian cause, he was set the task of "turning" Arab prisoners of war to the Arab side. In his memoirs he recorded that he did not have much success. Arab officers were not inclined to change sides as many feared for their families, or they were in camps where they were mixed in with Turks, "[whose] presence acted as something of an antidote to my exhortations-my eloquence was of no avail." ${ }^{61}$

In fact, the great majority of the Arab officers in the Ottoman army stayed loyal right to the end. Recent research has shown that the received wisdom of mass treason is simply incorrect. "The Ottoman Arab officers

57 Ibid., 140. The officer who spoke to Dabbous was, most likely, Major General Chayton, the New Zealander in command of the Anzac troops. See Faulkner, Lawrence of Arabia's War, 439.

58 Faulkner, Lawrence of Arabia's War, 186.

59 Eliezer Tauber, The Arab Movements in World War I (London: Frank Cass, 1993), 104-105.

60 Jafar Al Askari, A Soldier's Story. From Ottoman Rule to Independent Iraq: The Memoirs of Jafar Al Askari (London: Arabian Publishing, 2003).

61 Ibid., 111. 
did not desert en masse. Instead, most of them fought until the very end." ${ }^{62}$ This was due to a mix of professionalism, a feeling of shared destiny with Turkish officers, and a long period of training in Ottoman military academies. In fact, some Arab officers actually volunteered to fight in Mustafa Kemal's forces against the Greeks in the war of 1919-1922. ${ }^{63}$

Among the other ranks, given the brutality of Cemal's regime, the rate of Arab desertion from the Ottoman armed forces remained low. The massive desertions predicted by the British Arab Bureau in Cairo never materialized. According to British sources, out of a total of 7,233 Ottoman deserters and prisoners in 1917, 64 percent were Turks, 27 percent were Arabs. ${ }^{64}$

The Harb Mecmuası (The War Gazette) was a heavily illustrated propaganda magazine that was published with the aim of garnering support for the war effort among the Turks on the home front. ${ }^{65}$ Eyal Ginio has shown that the photographs of Arab soldiers contained within the magazine portrayed them as loyal, courageous, and ready to follow the lead of their Turkish officers. Moreover, units like the camel corps (hecinsuvar alayl) received special emphasis as they preserved the traditional Bedouin way of life, that of riding camels, and yet had been taught to combine this traditional skill with the use of sophisticated weaponry while facing the British. "This was clearly presented as an accomplishment by their Ottoman officers and instructors." ${ }^{\prime \prime 6}$ Thus, for the home front (or whoever else who could read Turkish), the Arab soldiers were presented in a way that was the very opposite of the way they were actually seen by their Turkish officers at the front.

Some officers did, however, develop a feeling of genuine respect for their Bedouin fighters. In Ateşve Güneş, the book that Falih Rıfkı wrote immediately after his return from Syria and which served as the first draft of Zeytindağ $ı$, we see a much more moderate tone regarding Arabs. In the section taken from the notebooks of an unnamed officer, the Bedouin are

62 Mesut Uyar, "Ottoman Arab Officers between Nationalism and Loyalty During the First World War," War in History 20, no. 2 (2013): 527-544.

63 Beşikçi, The Ottoman Mobilization of Manpower, 256.

64 Ibid.

65 Eyal Ginio, "Presenting the Desert to the Ottomans during WWI; The Pespective of the Harb Mecmuası," New Perspectives on Turkey 33 (2005): 43-63.

66 Ibid., 59. See Plate 9 in this volume depicting the officers of the Ottoman Camel Corps. 
portrayed as loyal and courageous fighters. The unnamed officer recounts how he came to make the acquaintance of a Bedouin sheikh:

At first I was not much impressed by his appearance. But when he spoke he was so brave, so frank, and inspired such confidence, I did not hesitate to share my plan [of action] with him.

The same officer also recounted how he had the Sheikh read a passage from the Qur'an to fortify the morale of his troops before they went into action. The Bedouin fighters went on to acquit themselves very well during the attack on the Suez Canal, inflating animal skins to support them as they could not swim. ${ }^{67}$

In the final months of the war, and as the Arab Revolt gathered momentum, the discord between Arab and Turkish troops became discernible. Liman von Sanders noted in his memoirs:

The [Turkish] troops disliked to receive Arab soldiers though they might be well trained, because they no longer trusted them, since the Arab movement in favor of the British was progressing. ${ }^{68}$

\section{The Holy War "Made in Germany" 69}

On November 14, 1914, The Shaikh ul Islam of the Ottoman Empire officially declared a Holy War (jihad)..$^{70}$ As the Sultan was also officially the Caliph of Islam and at least nominally the leader of the (Sunni) Muslim world, the Ottoman state had a pivotal role in the world of Islam. The declaration was made largely at the instigation of Germany, where many decision makers believed that a declaration of Holy War on the part of their Ottoman ally would lead to mass uprisings of Muslims in the empires of Britain, France, and Russia. Yet, it soon became evident that the mass upheavals would not occur and that even among Arab Ottoman troops Muslim solidarity was thin on the ground. A leading German who participated in the Suez Canal Campaign commented that the performance of the Arab troops was "a squalid fiasco." Yet, the same observer later stated,

67 Falih Rıfkı Atay, Ateşve Güneş [Sun and Fire] (Istanbul: Pozitif Press, 2009), 69, 72, 73.

68 Sanders, Five Years in Turkey, 218.

69 This term was coined by the famous Dutch orientalist Snouck Hurgronje in his book The Holy War "Made in Germany" (New York: Putnams and Sons, 1915).

70 Eugene Rogan, The Fall of the Ottomans (New York: Basic Books, 2015), 52. 
"we did not have any Muslim deserters."71 In the Arab lands of the Ottoman Empire, it was felt that shared religion would cement the already existing ties between Turks and Arabs. Cemal Pasha himself, although a totally secular individual, felt that " $[t]$ he majority of Arabs would not hesitate to make any sacrifice in this great war for the liberation of the Muslim Caliphate."72 In one of his numerous speeches before his reign of terror in Syria, Cemal called on the Syrian youth to support the holy war: "Together with the allies that we acquired almost by [accidental] good fortune we have not hesitated to declare jihad against those who have been the enemies of our religion for centuries." ${ }^{3}$ The reference here to allies "acquired almost by good fortune" (adeta tesadüfün bize verdiği müttefikler) is very significant, because the Ottoman jihad was in fact a "selective jihad." As humorously put by Sean McMeekin, "Death to Infidels Everywhere! (Unless they be Germans, Austrians, Hungarians, Americans or-possibly-Italians)." ${ }^{74}$

In fact, the jihad seems to have had not much effect in the Arab lands. Quite to the contrary, the call to arms and military conscription (seferberlik or safarbarlik) came to be synonymous to ruin in much of the Arab lands, and the term became an integral part of the negative stigma of the eyyam atrak. ${ }^{75}$ The Arab troops that were taken into the Ottoman armies were there because they had no choice, not necessarily out of a feeling of Muslim brotherhood.

\section{The execution of the martyrs and Cemal Pasha's reign of terror}

Together with the famine and the safarbarlik, the other key marker of the eyyam atrak was the execution of the martyrs by Cemal Pasha in Beirut and Damascus in 1915 and 1916. In Beirut on August 21, 1915, and in Damascus and Beirut on May 6, 1916, Cemal ordered the hanging of thirty-two Arab patriots. The notorious courts martial at Aley were nothing more than show trials, with few acquittals and death sentences in absentia. Some death sentences were reduced to imprisonment, and some of

71 Sean McMeekin, The Berlin-Baghdad Express: The Ottoman Empire and Germany's Bid for World Power (Cambridge: Harvard University Press, 2010), 172, 177.

72 Jamal Pasha, Memoirs of a Turkish Statesman (London: Hutchinson \& Co, 1922), 144.

73 Cemal Pasha, Hatıralar (Istanbul: Iş Bankasi Yayınları, 2008), 245.

74 McMeekin, The Berlin-Baghdad Express, 123.

75 Laila Fawaz, A Land of Aching Hearts (Cambridge, MA: Harward University Press, 2014), 161-204. 
the accused were released after being subjected to torture: "the aged and venerable Shukri Pasha al-Ayyubi was flogged day after day within inches of his life." ${ }^{76}$ All of the victims were prominent men, intellectuals, journalists, poets, or politicians. Among the executed there were Christians as well as Muslims. The wide spectrum of victims meant that the event would become part of the unifying foundational legend of the Lebanese state, as the hatred of Cemal would prove ecumenical. Youssef Mouawad has shown that the commemoration of Martyrs Day (May 6), beginning in 1934, was initially a bid to unite Muslims and Christians in Lebanon. ${ }^{77}$ This event was to become a watershed in Arab-Turkish relations as it became clear to most of the Arabs of the empire that the end of the road had been reached as far as loyalty to the Turks was concerned. In the memorable words of George Antonius, "Jamal's savagery burned all bridges between Turks and Arabs." ${ }^{18}$

Tarif Khalidi sums the situation up wonderfully:

Perhaps no single political event of the war could compare with the impact of the public hangings of prominent nationalists in 1915-1916. The shock waves were felt throughout Greater Syria. . . . Anger, horror, sullen resentment were directed at Jamal Pasha. . . This widespread anger would soon be transformed into the realization that the days of the empire were numbered. $^{79}$

Jafar Al Askari, whom we have met above, declared that when he heard of the execution of many of his friends he immediately decided to join the Arab Revolt: "I made up my mind there and then to seek revenge, and to make every effort to join the Sharif of Makkah at the earliest possible opportunity." 80

A contemporary Arab notable, Salim Salaam, was to make the following statement to a high Ottoman official immediately after the war:

You know what Cemal Pasha did to us in Syria. It was not enough for him to inflict persecutions, imprisonment and torture on us, but beyond this he

76 Antonius, The Arab Awakening, 202.

77 Youssef Mouawad, “1915-1918: La Grande Famine du Mont Liban," Historia: Une Histoire du Liban des Phéniciens a Nos Jours (December 2016-January 2017): 444-445.

78 Antonius, The Arab Awakening, 190, 192.

79 Tarif Khalidi, “The Arab World," in The Great World War, 1914-1945, vol. 2: The Peoples' Experience, eds. J. Bourne, P. Liddle, I. Whitehead et al. (London: HarperCollins, 2001), 298. See also Fawaz, The Land of Aching Hearts, 242.

$80 \mathrm{Al}$ Askari, $A$ Soldier's Story, 30. 
had sent a great part of our men and women and children into unknown Anatolia. Therefore we hate him, and we want to take revenge by any possible opportunity. ${ }^{81}$

One of the leading figures who was arrested, Mohammad Jafar El Safa, a prominent alim (scholar) from Jabal Amel, wrote extensively about the persecutions of Cemal Pasha. As to the reason for Cemal's acts, he writes:

$[\mathrm{O}]$ ne was that Jamal felt that the Free Arabs were inclined to revolution because of their traditional hatred for the Turks, and because of the great misery of the country because of the civilian and military misadministration before and during the war. Another version was that Jamal Al Saffah, because of his nature was inclined to murder and repression and was looking for an opportunity to terrorize the Secret Arab Association. ${ }^{82}$

First and foremost, in the memoirs of Cemal Pasha, it is clear that the perpetrator of the executions was entirely unrepentant and attempted to justify his actions. Cemal maintained that he was convinced that a largescale uprising was being planned in Syria and Lebanon. The French Consul in Beirut, Georges Picot (of Sykes-Picot fame) had neglected to destroy incriminating documents before he left at the beginning of the war. A member of the embassy staff informed the Ottoman authorities of the hidden compartment in the embassy which was broken into and the documents confiscated. These documents formed the basis for the prosecution of the Arab patriots for "treason." ${ }^{83}$ One of the leading figures in this somewhat scandalous breech of diplomatic protocol, as the consulates were under the protection of the neutral American consul, was the notorious CUP hitman (fedai) Kuşcubaşı Eşref Bey. In his personal papers Eşref recounts proudly how he and his staff were responsible for finding the "evidence" to convict the accused men. The documents seized amounted to some thirty-one boxes. ${ }^{84}$ Cemal maintained in his memoirs that he refrained from using the

81 Christoph Schuman, "Individual and Collective Memories of the First World War" In The First World War as Remembered in the Countries of the Eastern Mediterranean, ed. Olaf Farschid et al. (Beirut: Orient Institute, 2006), 246-263. This statement is all the more remarkable as Salim Salaam was one of the few Lebanese notables who was actually seen as above suspicion by Cemal.

82 Mohammad Jaber El Safa, Tarikh Jabal Amel (Beirut: Dar el Nahar, 1918), 213.

83 See Fawaz, The Land of Aching Hearts, 243-249, and Rogan, The Fall of the Ottomans, 292-296.

84 Benjamin Fortna, The Circassian. A Life of Eşref Bey, Late Ottoman Insurgent and Special Agent (London: Hurst, 2016), 49, 172-173. This is a fascinating account 
evidence, the documents seized from the French Consulates in Beirut and Damascus, because he hoped that the nationalists could be won over to the Ottoman cause: "The policy I desired to see pursued in Syria was a policy of clemency and tolerance. I left no stone unturned to create unity of views and sentiments in all the Arab countries."

Cemal went on to state that although he had ample evidence against the suspects he refrained from pursuing them, hoping that they would see the light and rally to the banner of Islam. ${ }^{85}$

In 1913 an Arab Congress had met in Paris to discuss the future of the Arab provinces. The Ottoman government had sent official observers to the meeting. During private meetings with French officials, when Turkish officials were not present, some of the Arab delegates had made compromising declarations regarding willingness to come under French rule. These were among the documents later seized by Cemal during the war and used as evidence against the Arab patriots. "Yet a unified opposition to Istanbul did not exist and did not materialize before the Great War." ${ }^{\text {6 }}$

Yet suspicion of just such an opposition was rife even well before the war. Mahmud Nedim Bey, one of the leading Young Turks recounts a conversation in 1909 with Talat where Talat told him that he had grave suspicions about the activities of the Arab intellectuals in Istanbul: "We are not so foolish as not to see what they are after. What gets on my nerves the most is that they show us a smiling countenance, seemingly sincere and loyal, they take us for fools and laugh at us behind our backs. ... No matter how much they smile at us, they are our opponents. ..."87

Mahmud Nedim Bey also mentions a conversation with Abdul Hamid al Zahrawi in Istanbul before the war where he stressed that he saw the need for reform in the Arab provinces, but counseled patience and moderation.

I told him, "you must not threaten us. When you want something from the government you seem to be threatening us, your attitude is almost military. You seem to be relying on the Syrians."

based largely on the personal papers of this highly controversial figure. Eşref Bey was a founding member of the Special Organization (Teșkilatı Mahsusa) that was the Ottoman intelligence service. It was also infamous for its role in the perpetuation of the Armenian Genocide. Fortna pithily refers to Eşref as having "transferable skills."

85 Jamal Pasha, Memoirs of a Turkish Statesman, 201.

86 Fawaz, A Land of Aching Hearts, 24-25.

87 Mahmud Nedim Bey, Arabistan'da bir Ömür: Son Yemen Valisinin Hatıraları [A Lifetime in Arabia: The Memoirs of the Last Vali of Yemen] (Istanbul: ISIS Press, 2001), 177-178. 
Zahrawi told him that they had lost patience with the government and that they "were running out of time." 88

Hasan Kayalı, in his classic book on Turkish Arab relations during the Great War stated that by ordering the executions Cemal was not overreacting to "sensational revelations" and that he was "convinced that a nationalist movement in Syria was a real, if not an imminent threat." ${ }^{89}$ As such it had to be nipped in the bud.

Recent research in the Ottoman archives has shown that Cemal wrote to Talat as early as the beginning of May 1915 informing him that he was planning to do away with Abdul Hamid al Zahrawi and the other Arab nationalists well before the courts martial at Aley even began. Zahrawi, who was a member of the Ottoman Senate, was in Istanbul at the time that Cemal decided to go after him. He wrote to Talat, asking him to send Zahrawi to Syria, but Talat hesitated, fearing that Zahrawi's arrest would cause an uprising. However Cemal insisted that he wanted to take this opportunity to "finish him off." Talat relented and Zahrawi was sent to Syria. Cemal used a supposed uprising that was being prepared in Sur and Sayda by Abd Al Karim al Khalil and Rida al Sulh as an excuse to persecute the Arabists. He referred to them using insulting language, telling Talat that he would prevent any uprising by, "breaking the heads of these accursed (mel'un) people." In his letter, Cemal declared to Talat that

Finally, during the Entente's campaign in Gallipoli, they [the Arabists] assumed that the collapse of [the Ottoman] government was imminent and they began to propagandize in the vicinity of Sur, Sayda and Merc Uyun. So I put my hands on their shoulders (işte o zaman onların omuzlarına ellerimi yapıştırdım). ${ }^{90}$

Talat was right to fear an uprising over the arrest of Zahrawi. In a book published before the war, Khairallah Khairallah, a prominent Christian intellectual, lauded Zahrawi to the skies stating that he was a fine example of an Arab leader who was always ready to oppose the government. As for his

88 Ibid., 182.

89 Hasan Kayal, Arabs and Young Turks: Ottomanism, Arabism and Islamism in the Ottoman Empire 1908-1918 (Los Angeles: University of California Press), 194.

90 Çiçek, War and State Formation in Syria, 44-45. 
popularity, Khairallah stated, "For the people it was more than sympathy and esteem, for them [Zahrawi] was a cult figure."

How real was the danger of the conspiracy in Sur? One of the movement's early participants was Mohammad Jafar El Safa' who stated in his memoirs: "The ahrar, the free people among the Arabs, took the opportunity of anger against the government and the fact that it was occupied with the war and set about working for the awakening of the Arab Movement in Syria." From his account it appears that such a movement did indeed exist,

On 18 October 1914 the ahrar designated as delegate for Sayda and Sur and Jabal Amel, the martyr Abd el Karim Qasim Al-Khalil.... He was among the best of the young Arabs in education and merit and national zeal. He enjoyed a distinguished reputation in the Jabal Amel. He had little experience and great temerity. He was not completely aware of the traditional conditions of the country and the situation of the zuama (local feudal lords) of Jabal Amel. He was over hasty and out of dedication created a cell of the Association [of the Arab Revolt] in Saida, composed of a category of persons who were uninformed and unreliable. Some disclosed his secret and turned against him from one day to the next. Some out of ignorance and stupidity and others out of malice and yet others out of treason and pro-Turkish sympathies."92

In fact, $\mathrm{Al}$ Khalil was betrayed to Cemal by several informants, including members of his close circle. It is doubtful that the Arabists in Syria had enough mass support or a definite plan. According to "celebrated German orientalist" Martin Hartmann, who was attached to the German army, "the Arabist movement was not strong enough to drag its members into a revolt against the Ottoman government." 93

George Antonius's view is that there was in fact a plan, largely prepared by the secret society $\mathrm{Al} A \mathrm{~A} d$, to stage a rising but fact and rumor merged to such an extent that uncertainty prevailed:

Military intelligence is seldom at its best in following up political clues; and the General Staff of the Fourth Army was no exception; while it had an ear for rumors, its nose failed to pick up their scent. The information was substantially true, but it could not be traced home to any of the plotters,

91 K.T. Khairallah, La Syrie, Territoire, Origines Ethniques et Politiques, Evolution, Esquisses: La Vie Sociale et Littéraire, la Vie Politique en Syrie at au Liban (Paris: Ernest Leroux, 1912), 128.

92 Jaber El Safa, Tarikh Jabal Amel, 212.

93 Ibid. See also Çiçek, War and State Formation in Syria, 47. 
$\mathbf{x l} \mid$ Introduction

and Jemal was disturbed and it made him anxious and vindictive but bewildered. ${ }^{94}$

As a result, Cemal cast his net far and wide, pursuing the innocent as well as the "guilty." He justified his acts by claiming that the only troops he had at his disposal were Arab and if these had mutinied he would not have been able to save Syria:

I decided to take ruthless action against the traitors. ... [As the courts martial proceeded,] the wide range of their plotting simply astounded me. At this time the only troops in Syria were Arab regiments, and if these had mutinied I should have nothing with which to quell the revolt. The battle at the Dardanelles was raging in all its fury, and it was out of the question to take a battalion let alone a division from that front. ${ }^{95}$

He defended his decision to order the executions without reference to Istanbul by the extensive powers granted to him by wartime conditions:

After reading the proceedings of the courts martial and obtaining the views of the Judge Advocate General, I confirmed the sentence of death, and it was carried out the following day at Beirut. ${ }^{96}$

It is remarkable that the Turkish official military history of the First World War echoes Cemal's words:

Because most of the troops in the region were Arabs, if these were to mutiny the army would be left with nothing. That is why the Fourth Army, in order to save the future of Turkism and Arabism, did not hesitate to punish them in exemplary fashion by carrying out their sentences in Beirut. Some local and foreign sources who have been deceived, link the Arab Mutiny to the hanging of the Syrian and Lebanese traitors. This is wrong. Sharif Husain's mutiny had nothing to do with the hanging of the traitors. ${ }^{97}$

Thus in an official publication which appeared in the 1970s the Arab patriots are seen as "traitors." A better example of the longevity of the "stab in the back syndrome" could not be wished for.

94 Antonius, The Arab Awakening, 186.

95 Jamal Pasha, Memoirs of a Turkish Statesman, 213.

96 Ibid.

97 Birinci Dünya Harbinde Türk Harbi, 336, 338. 
In his memoirs Ali Fuad Erden gives a detailed account of how Colonel Şükrü Efendi, the chief judge on the tribunal in Damascus, came to him with the result of their deliberations and the suggested sentences. He asked Ali Fuad to intercede with Cemal in order to approve the sentences. Out of the twenty accused only four had received the death penalty. Cemal personally changed all the sentences to death by hanging, brutally overriding the decision of the court. ${ }^{98}$ Yet, Ali Fuad also stated, "A few days later Cemal Pasha would approve these convictions in the name of the Turkish nation and he would order their carrying out, again in the name of the Turkish nation." 99 Thus, it was "the Turkish nation" that hanged the Arabs.

Indeed, it seems that Cemal actively cultivated his image as the source of terror. Falih Rifk 1 was to witness how Cemal seemed to take pleasure in flaunting the evidence in the face of the accused. One of the few instances in Zeytindağ 1 where Rifkı comes close to criticizing his commander is found in his description of how Cemal took pleasure in humiliating his victims. ${ }^{100}$

It is clear that Cemal was determined above all else to make an example of the hanged men. He repeatedly turned down pleas for clemency, even from Talat who interceded for Zahrawi, and from Sharif Husain who warned that the death penalty would lead to a situation where "blood will cry out for blood." 101 There is little doubt that the execution of a whole generation of Arab intellectuals by Cemal Pasha was what earned him his title of "The Blood Shedder" (Jamal al-Saffah). Yet this was not his only title. Aziz Bek, Cemal's head of intelligence in the Fourth Army district, compiled a whole string of flattering epitaphs that the people of Syria used for him: "Jamal al Zalim! (The oppressor!), Jamal al Taghiya! (The tyrant!), Jamal Mutawi' al bilad! (He who starved the people!), Jamal Hatik al-a'rad! (Violator of women's honor!)"102 The people of Syria felt humiliated because they saw the hangings as "collective punishment." It has been estimated that Cemal sent thousands of Syrians into exile; indeed, he bragged about this, telling Falih Rıfk1, "everywhere there are those who I sent there."103

98 Ali Fuad Erden, Birinci Dünya Savașında Suriye Hatıraları, 325; see below, p. 129.

99 Ibid., 275.

100 Falih Rifkı Atay, Zeytinda $\breve{g}, 37$.

101 Rogan, The Fall of the Ottomans, 295.

102 Fawaz, A Land of Aching Hearts, 241.

103 Ibid., 245. 
Among the close observers of Cemal Pasha's iron rule in Syria and Lebanon was the President of Syrian Protestant College (today the American University of Beirut), Dr. Howard Bliss. The United States did not join the war until 1917 and the position of the college was delicate. Cemal deeply mistrusted the American staff of the college and suspected that it was a hotbed of Arab nationalism. Howard Bliss was to admit that, "Among the people of Syria there has always been a strong feeling of opposition to the Turkish regime, and Constantinople has always suspected the loyalty of this province. It now believes that Syria is a hot bed of sedition." Bliss admitted that some of the graduates and students of the college were associated with the "Arab movement" but insisted that it was unfair on the part of the Turks to make this a basis for a general charge of seditious activity against the college. Soon after the first executions Bliss was to pen one of the most accurate assessments of the Young Turks' state of mind:

. . The group of men in control of the Empire are determined, able, unscrupulous, and violent men. They are flushed with unexpected success. They will go just as far as in the direction of desperate measures as they dare. They are playing for high stakes. They must win or lose everything. ${ }^{104}$

The martyrs became a foundation legend in Syria and Lebanon in the years after the war and came to epitomize the idea of the "dark days of the Turks." As shown in the seminal work of James Gelvin, "The initial attempts to create meaning from the executions ordered by Jamal Pasha were made by those who participated in the Arab Revolt and their supporters who worked with the Arab government." Memorial ceremonies were carried out and patriotic plays were produced featuring "Jamal Pasha the Butcher." ${ }^{105}$ Nicolas Z. Ajay, somewhat exaggeratedly, compares, "[T]he feelings of the Lebanese toward the Turks, [which are] somewhat akin to that of the Armenians and Greeks toward the Turks." 106

Yet Gelvin is critical of the "myth of the executions" as "a critical boundary in the history of the evolution of the Arab movement" which has

104 American University of Beirut Archives, Howard Bliss Collection, Box 16 AA 2-23-2 16-6, "The Syrian Protestant College and the Ottoman Government: A forecast of some of the more or less remote contingencies in the course of the war's progress," a seventeen-page report dated February 1916.

105 James L. Gelvin, Divided Loyalties: Nationalism and Mass Politics in Syria at the Close of Empire (Berkeley: Cambridge University Press, 1998), 256.

106 Nicolas Z. Ajay, "Political Intrigue and Suppression in Lebanon during World War I," IJMES 5 (1974): 140-160. 
become "commonplace among historians of 'Arab nationalism." He points out that even after the executions, "Jamal Pasha was frequently feted and celebrated by Damascenes, many of whom would later figure prominently in nationalist activities." ${ }^{107}$

Gelvin's analysis tallies with Rifki's and Fuad's accounts of base flattery even after the executions. However Gelvin tends to minimize the collective horror and terror that the executions did create. Self-seeking flattery or compliance as a means of self-preservation can be easily combined with a secret loathing toward the cause of the suffering.

As we see in the memoirs of Anbara Salaam, she refers to Cemal Pasha as "a monster" because he had hanged her fiancée. Nonetheless, at the behest of her father Salim Ali Salaam, she is made to be present at a social function where she is obliged to make a speech in Cemal Pasha's presence, even receiving his compliments. Salaam notes in her memoir, "the words of congratulations I heard for my speech felt like a series of stabs at my heart." ${ }^{108}$

There were also prominent locals who out of self-interest or genuine Ottoman patriotism supported Cemal Pasha. One of the most prominent was Emir Shakib Arslan, a Lebanese Druze aristocrat who remained a committed Ottoman loyalist to his dying day. He established himself as Cemal's right hand man and, "an intermediary between Jamal Pasha and the Arab populace." Arslan came to be hated as a collaborator and this stigma followed him to the end of his days. ${ }^{109}$

Another prominent supporter was Shaikh As'ad al Shukairi, who became infamous for issuing fatwas in support of the executions. $\mathrm{He}$ was later to be roundly condemned as a collaborator. Salim Al Ya'qubi was another important personage who backed Cemal, a leading religious scholar and poet, in 1916 Al Ya'qubi, issued a fatwa condemning Sharif Hussein. He retained his pro-Ottoman sympathies even after the Allied entry into Syria. ${ }^{110}$

107 Gelvin, Divided Loyalties, 176.

108 Anbara Salaam Khalidi, Memoirs of an Early Arab Feminist: The Life and Activism of Anbara Salaam Khalidi, trans. Tarif Khalidi (London: Pluto Press, 2013), 70

109 William L. Cleveland, Islam Against the West: Shakib Arslan and the Campaign for Islamic Nationalism (Austin: University of Texas, 1985), 31: "Arslan quickly established himself as an intermediary between Jamal Pasha and the Arab populace." As Cemal did not speak Arabic, his speeches would be translated by Shakib Arlan or As'ad Shukairi.

110 Salim Tamari, "Muhammad Kurd Ali and the Syrian-Palestinian intelligentsia in the Ottoman campaign against Arab separatism," in Çiçek, Syria in World War I, 37-60. 
In order to justify and legitimize his policy of terror, Cemal Pasha published a book giving the official line on the courts martial at Aley and the subsequent executions. Published in Arabic, Turkish and French, the "Red Book," as it came to be called, remains a masterpiece of propaganda. ${ }^{111}$ The point that is adamantly hammered home in the introduction and several times in the text is that "[o]ne cannot insist enough on the essential point: the trial carried out by the court of Aley was in no way a matter of nationalism; it was a simple matter of high treason." Cemal very ably played on the Arab sense of honour by declaring:

... those individuals who have received the just punishment for their acts have soiled the good name of the Arabs in the eyes of statesmen of the enemy countries and have made them believe that this race has no morals or character and would yield themselves up to the first invader to occupy their lands. ${ }^{112}$

The introduction took pains to point out that the plotters were only a small group who "abused the good faith of the Arab nation, the great mass of whom, proletarians, bourgeois and aristocrats remained outside their movement." The Red Book stressed that the courts martial "only tried and condemned some two hundred individuals, as many Muslims as Christians" ostensibly proving that the movement was a very restricted one. ${ }^{113}$

Another important aspect of the Red Book was its justification for the policy of exile. ${ }^{114}$ In describing the various categories of individuals who were exiled, the "second category" after the actual families of the condemned, are the "feudal class" who had oppressed the population, exploited their servitude, and had moreover,

always opposed the efforts of the government which was trying to assure an equitable partition of the land and to defend the right of the population to enjoy the fruits of their labour. They always tried to oppose all the efforts of the government to uplift the working man. ${ }^{115}$

111 La Vérité sur la Question Syrienne. Publié par le Commandement de la IV ème Armée (Stamboul: Imprimerie Tanine, 1916). Although Cemal does not clearly appear as its author, the publication clearly reflects his views as seen in the Turkish and English versions of his memoirs.

112 Ibid., 7-8.

113 Ibid., 9.

114 Cemal Pasha exiled some 5,000 Syrians to Anatolia. See Çiçek, War and State Formation in Syria, 51; Rogan, The Fall of the Ottomans, 291. Rogan gives the number of deported at 50,000 this is probably and exaggeration.

115 La Vérité, 154. 
Even more brazen than Cemal the friend of the working man was Cemal who "did not deport but simply transported these families... . Nothing changed, a compatriot who was Syrian became a compatriot who was from Bursa."116

\section{The end of Lebanon's autonomy}

The country which is today Lebanon was divided into two administrative units during Cemal Pasha's rule of the Fourth Army district: The Vilayet (Province) of Beirut, established in 1888, and the Mutasarifiyya (autonomous province) of Mount Lebanon. The Mutasarrifiyya had an autonomous status regulated by the Réglement Organique of 1861 which had come into force following its signature by the Sublime Porte and the ambassadors of the Great Powers. Although it was officially part of the Ottoman Empire, it was overseen by a Christian governor called the Mutasarrif, who was appointed by the Ottoman Sultan, but with the approval of the signatory Great Powers. He had to be an Ottoman Christian. The special status of the Mutasarifiyya did indeed allow for considerable autonomy from direct Ottoman rule. Cemal Pasha never officially abrogated the Mutasarifiyya but in 1915, after the last Christian Mutasarrif Ohannes Pasha Kouyoumdjian was forced to resign, a Muslim Mutasarrif was appointed, de facto ending Lebanese autonomy. ${ }^{117}$

The first Muslim Mutasarrif was Ali Münif Bey, a close associate of Talat Pasha. He wrote his memoirs in the late 1940s. ${ }^{118}$ Although he dedicated only a short chapter to his period as Mutasarrif, it is a remarkable source. The most striking statement Münif makes is his assessment of his relations with Cemal Pasha:

The only difficulty I experienced during my duties in Lebanon was Cemal Pasha. As he was alienating the population with his ruthless measures, I was seeking to mend the damage and win back their affection. In fact this was one of the reasons why I had been sent to Lebanon as governor. ${ }^{119}$

116 Ibid., 156-157.

117 Engin Akarl, The Long Peace: Ottoman Lebanon 1860-1920 (Los Angeles: University of California Press, 1993). See also the memoirs of Ohannes Pasha Kouyoumdjian, Le Liban. A la Veille et au Début de la Guerre: Mémoires d'un Gouverneur 1913-1915 (Paris: Centre d'histoire arménienne contemporaine, 2003).

118 Taha Toros, ed., Ali Münif Bey'in Hatıralart [The Memoirs of Ali Münif Bey] (Istanbul: ISIS Press, 1996). The memoir was first published as a serial in the Akşam newspaper in 1955.

119 Ibid., 71. 
Münif stated that the main source of conflict between the two men arose over the issue of the military intervention in the Mountain and the fact that the Pasha was not sensitized to "the traditions and legal practices of Lebanon." Yet he maintained that over time they developed a friendly relationship.

The official ferman (Imperial order) declaring Münif as Mutasarrif began by announcing, "The privileges of Jabal Lubnan have been abrogated!" It went on to declare that the autonomous status of the Mutasarifiyya and the appointment of a Christian Mutasarrif with the approval of the foreign powers was to end forthwith.

Yet, the new governor attempted to soften the blow by declaring in a speech that the previous practices would be continued and that the Mountain would not be subjected to conscription. Münif stated in his memoirs that "because I was aware of the sensitivities of the local population," he had prepared his speech with great care. He confidently declared that " $[t]$ he people of the Jabal were content, they became even more affectionately attached to their Muslim Mutasarrif [than the Christian ones]."120

Indeed, a contemporary Lebanese writer, Lahad Khater, gives a very balanced view of the short tenure of Ali Münif Bey (September 25, 1915May 15, 1916). ${ }^{121}$ On the positive side, it is stated that he administered "with wisdom and rigor," that he prevented military intervention in the affairs of the Mountain, and that he shut out the old coteries of opportunists that clustered around previous Mutasarrifs. ${ }^{122}$ However, on the negative side he was implicated in a company formed by a leading Beiruti that monopolized the wheat market, "The wheat was sold on the black market at exorbitant prices, which greatly aggravated the famine and enriched [Ali Münif] enormously. This was the price that was paid by the souls who perished." ${ }^{123}$

In mid-May 1916 Münif was appointed the Vali of Beirut and held the position until mid-1918. ${ }^{124}$ The position of the last Christian Mutasarrif of Lebanon, Ohannes Pasha Kouyoumdjian, a highly sophisticated Ottoman diplomat, who was an Armenian Catholic, became more and more difficult.

120 Ibid. See below Falih Rifki's account of Cemal Pasha's speech on the new status of Lebanon.

121 Lahad Khater, Ahd al Mutasarrifin fi Lubnan [The Period of the Mutasarrifs in Lebanon] (Beirut: Editions Lahad Khater, 1982).

122 Ibid., 203.

123 Ibid. The Beiruti in question was Alfred Sursock, a close associate of Cemal Pasha.

124 Ibid., 204. 
The Administrative Council of the Mutasarffiyya was abolished on May 15 and its legally elected members were replaced by men who were chosen by Cemal and Münif. This was the last straw for Kouyoumdjian, who presented his resignation to Cemal. ${ }^{125}$ Thus ended the fifty five years of the "Long Peace" of the Mutasarrifiyya period. ${ }^{126}$

Kouyoumdjian had become convinced that Cemal had indeed singled out Lebanon for special treatment. At his first meeting with the Mutasarrif, Cemal made a point of enumerating a long list of grievances against the Lebanese. As proof he brandished a book by a Syrian author, declaring vehemently:

I will use their own testimony against them. In nearly all the pages of this book, there is clear evidence that the Lebanese, more particularly the Maronites, are traitors and criminals acting against their sovereign. . . . It is high time that we clamped down on these unfaithful infidel subjects and make them realize that there is no other salvation other than sincere submission to Ottoman rule. ${ }^{127}$

The book in question, written by Khairallah Khairallah, a prominent Christian intellectual, did indeed make open references to France as the "traditional protector of the Maronites" since the time of the medieval kings of France. Cemal may well have objected to statements such as, "The Turkish intellect lacks prestige and assimilative power. Its misfortune is the fact that it is faced by an intellect [the Arab] that is superior to it socially and morally. This means that the Turkish element can never prevail without tyranny". ${ }^{128}$ The message of the book was clear, Syria and Lebanon were to come under French protection. ${ }^{129}$

There is little doubt that in Cemal's risk analysis for Lebanon, the greatest danger he saw were the Maronites. It was well known that they were pro-French and were demonized to the extent that even in the official archival publication of the modern day Turkish chiefs of staff we read the following remarkable words:

125 Ohannes Pasha Kouyoumdjian, Le Liban, 148, 150. Cemal did not accept his resignation, referring him to the Grand Vizier Said Halim Pasha. Kouyoumdjian was accorded three months leave "for reasons of health."

126 Akarl, The Long Peace.

127 Ohannes Pasha Kouyoumdjian, Le Liban, 113.

128 Khairallah, La Syrie, 119.

129 Kais M. Firro, Inventing Lebanon (New York: I. B. Tauris, 2003), 23. 
The Maronites were sincere enemies of Islam. They were being supported from the outside. In Lebanon a sect called the "Holy Warriors" had been created. Every one of them who killed a Muslim was paid a salary of four liras if he was a bachelor and eight liras if he was married. Of course these monies were provided by the French and the British who generously showered their gold for propaganda purposes."130

This reference to a sort of sect of "Maronite Hashisheen" is repeated almost verbatim from Ali Fuad's memoirs cited below. ${ }^{131}$ Curiously, it is also included (down to the exact amount paid for each death) in Rifki's Zeytinda $\breve{g}_{\imath} .{ }^{132}$ Evidently, the negative stigmatization of the Maronite population as the atavistic enemy became an enduring racial stereotype.

Both Cemal and Ali Fuad sincerely expected a Maronite backed French landing in Lebanon. In both Cemal's and Fuad's memoirs Lebanon is depicted as the "weak spot" on the Syrian coast. There is frequent reference to the "thirty thousand rifles in Mount Lebanon." What is even more interesting is that the same concern is voiced verbatim in the official history of the Turkish military, "It was imperative to keep in mind the thirty thousand rifles in the hands of the people of the Mountain who were pro-French." 133

As Cemal was about to order a search for weapons in the Mountain, Kouyoumdjian intervened and declared that the people of the Mountain were indeed armed, but that these arms were purely for their own protection. As to the possibility of an armed rising against the Ottomans, he declared, "Unless they are driven to despair, the Lebanese will not rise. They have neither the courage nor the means to do so. They will move only if the enemy lands. Even then these prudent mountaineers will only join them if they are in sufficient numbers." 134

Cemal claimed that he did not order to search for arms because:

... it was certain that, whoever took in hand the business of disarming them, several illegal acts were bound to occur and many innocent people would be unnecessarily disturbed. Under the pretext of house searching the

130 Birinci Dünya Harbinde Türk Harbi, 690.

131 Ali Fuad Erden, Birinci Dünya Savaşında Suriye Hatıraları, 22.

132 Falih Rıfkı Atay, Zeytindă̆ı, 30.

133 Birinci Dünya Harbinde Türk Harbi, 107

134 Ohannes Pasha Kouyoumdjian, Le Liban, 97. 
propertied classes among the inhabitants of Lebanon were bound to suffer immense material damage. ${ }^{135}$

Cemal instead set out to harass the Maronite Patriarch Elias Howeyk who was known for his pro-French inclinations. He considered exiling the Patriarch to Anatolia but was prevented through the intervention of the Papal Nuncio in Istanbul, Monseigneur Dolce, and the Austrian government. Cemal humiliated the Patriarch, who traditionally never left his seat in Bkirké, by obliging him to visit him in Sofar.

When Cemal sent his personal car to fetch Patriarch Howeyk, Rifk1 was to make the snide comment, "The Maronites considered the Patriarch to be a god. It was amusing to see a god riding in a motorcar." ${ }^{136}$ Rifkı seemed to have a somewhat exotic view of Maronite beliefs. The Maronite Patriarch was not regarded as a god. One of the Jesuit fathers wrote in his diary that Cemal summoned the patriarch and gave him "two-days grace" to present himself, ostensibly to talk about famine relief. On the issue of the motor transport, Father Joseph Mattern wrote: "We are told of a rapprochement between his Beatitude the Patriarch and the Commander Cemal Pasha. They met in Damascus and travelled together by car as far as Jounieh. It seems that the Commander is in no way convinced of the Ottomanist sentiments of the Maronite nation. His Beatitude attempted to prove him wrong." ${ }^{137}$ One of the measures that the Maronites disliked the most was that Cemal Pasha removed the hitherto autonomous status of the Maronite patriarch making him an Ottoman official. ${ }^{138}$

The patriarch arrived in Sofar on July 25. According to Antoine Yammine, a Maronite priest who wrote one of the earliest accounts of Cemal's rule in Syria, Cemal was surprisingly affable, receiving the patriarchal delegation with great pomp and circumstance. He even arranged for a considerable amount of provisions to be sent to the visiting prelate's flock.

135 Jamal Pasha, Memoirs of a Turkish Statesman, 202-203.

136 Falih Rifkı Atay, see below, p. 50.

137 Tautel and Wittouck, eds., Le Peuple Libanais dans la Tourmente de la Grande Guerre 1914-1918, 35. See diary entry of Joseph Mattern for July 22, 1915. The Jesuit fathers, who were French nationals, had to leave Lebanon. Those who were either Lebanese nationals or nationals of Germany or Austria were allowed to stay. The work cited here is a compendium of the diaries of several Jesuits who were in Lebanon throughout the war.

138 Çiçek, War and State Formation in Syria, 91. Çiçek gives the date of the patriarchal visit as July 27. 
There was, however, a price to be paid. According to Yammine, Cemal prevailed upon the patriarch to issue a public statement that would be published in the French press, declaring that all was well in Lebanon and that " $[t]$ he myth that the authorities were deliberately organizing the famine by blocking the entry of food [to the Mountain] was a monstrous invention." The declaration also stated that the men who were executed had been proven to have undertaken traitorous activities, and that "all civilized states take such rigorous measures in similar circumstances." Yammine stated that the patriarch should not be held responsible for making the declaration because he had been forced to make it "in order to save the surviving members of his flock from a tiger thirsty for blood." 139

Howeyk was later to be criticized by the Maronite community for making this declaration "[and showing] weakness at one point of his protracted confrontation with the man who symbolized Turkish rule."

Archbishop Abdallah al-Khuri, who had been the go-between between Cemal and Howeyk, would publish in 1922, in the Jesuit founded newspaper al Bashira, a defense of the actions of the Patriarch; "In Al Khuri's narrative, the statement of good treatment from Jamal that the Patriarch would now sign was the latter's response to the existential crisis of Maronites in general that was now forcing him to negotiate and concede." ${ }^{140}$

After the war Patriarch Howeyk presented an official declaration to the Paris Peace Conference roundly condemning Cemal and the Turks in general for "atrocities and executions committed in Lebanon." In this document he demanded that Turkish officers and officials of all ranks should be tried as war criminals. ${ }^{141}$

Carla Eddé has given a detailed account of how Beirut and Mount Lebanon were "liberated" twice in October 1918. A few days after the departure of the Ottoman troops, Shukri Pasha al Ayyubi, the representative of

139 Antoine Yammine, Quatre Ans de Misère: Le Liban et la Syrie pendant la Guerre (Cairo: Imprimerie Emin Hindie, 1922), 61.

140 Dennis Walker, "Clericist Catholic Authors and the Crystallization of Historical Memory of WWI," in The First World War as Remembered in the Countries of the Eastern Mediterranean, ed. Olaf Farschid, Manfed Kropp, and Stephan Dahne (Beirut: Orient Institut, 2006), 91-127.

141 Elias Hoyek (Patriarche), "Les Revendications du Liban. Mémoire de la Delegation Libanaise a la Conference de la Paix," La Revue Phenicienne (Noel 1919): 24-288; Antoine L. Boustani, Histoire de la Grande Famine au Mont-Liban (1914-1918): Un Génocide Passé sous Silence (Beirut: Presse Chemaly et Chemaly, 2014), 86-87. 
Emir Faisal, arrived in Beirut on October 6. Although the Arab forces and Shukri Pasha were well received, there was some tension between them and the local notability regarding the division of power. ${ }^{142}$ It was finally decided that Shukri Pasha would preside in the Grand Sérail, which had long been the seat of the Ottoman Vali, and Omar Al Dauk, a prominent Sunni notable of Beirut and to whom the last Ottoman Vali had handed over the administration, would be installed in the Petit Sérail which had been the seat of the municipality. Salim Ali Salaam, another wealthy Sunni who had represented Beirut in the last Ottoman parliament and was dedicated to the Arab cause, represented the local notability at the celebration of their liberation. Dauk refused to attend. "In the presence of an enthusiastic crowd, the Sharifian flag was raised over the Grand Sérail, and the hutba was read in the name of Sharif Husain at the Friday prayer." ${ }^{143}$

However, this jubilation was not universal. Shukri al Ayyubi had also taken possession of the Mountain by occupying the palace of Baabda, the seat of the Mutasarrifiyya. This worried the Christian Lebanese. The Pasha tried to appease them by appointing Habib Pasha al Saad as the governor, Habib Pasha had been the president of the last Administrative Council dissolved by Cemal. Yet the anxiety of the Christian Lebanese increased when Habib pledged allegiance to Emir Faisal. The fact that both Beirut and the Mountain had declared in favor of the Sharifian side was intended to weaken the claims of the French. This show of united support for Emir Faisal was meant to enforce the claim to Arab independence. Yet, this measure actually worked in favor of the French. Sharif Husain had been obliged to cede Mount Lebanon to the French, who now complained that the Arabs had trampled on their "rights," obliging the British to come to their ally's aid. When the French in Lebanon asked the British to intervene in their favor the British could not refuse. On October 4, a French naval squadron was ordered to occupy Beirut and French marines landed the next day and immediately started to distribute food. On October 8 , the occupation troops arrived. Allenby ordered the lowering of the Arab flag and sent Shukri Pasha away. ${ }^{144}$ The second "liberation" had ended the first, which had lasted only two days.

142 Carla Eddé, Beyrouth: Naissance d’une Capitale 1918-1924 (Paris: Actes Sud. Sinbad, 2009), 44.

143 Ibid., 44.

144 Ibid., 45. 
lii | Introduction

\section{The Great Famine}

Together with the execution of the martyrs, the famine of the war years stands out starkly in the collective memory of the Arab lands in the last years of Ottoman rule. The famine was particularly disastrous for the population of Mount Lebanon. The death toll varies between 80,000 and 200,000. The widely held view is that Cemal deliberately starved the Maronite population in order to keep them weak and unable to rebel, as he knew that they were pro-French. A frequently repeated dictum is that Enver Pasha supposedly told Cemal, "we have done away with the Armenians by the sword. We will reduce the Christians of Lebanon by hunger." This statement is attributed to a Maronite priest who was working for French intelligence, and it was used extensively in French propaganda. A recent, somewhat controversial, book by Antoine Boustani openly contends that Cemal's actions against the Maronites amounted to genocide. ${ }^{145}$ This view is contested by Joseph Mouawad who states that the land blockade imposed by Cemal Pasha on grain imports to the Mountain was the main cause of the famine. Mouawad tends to be skeptical regarding the intelligence report mentioned above. $\mathrm{He}$ does, however, qualify what happened in more moderate terms, refusing to call it genocide, "given the evidence at hand," but he does declare that it was "a crime against humanity." 146

There were several factors that led to the famine. Grain and other foodstuffs were regularly requisitioned by the army. Local merchants also speculated and hoarded. The Allied blockade of the Syrian and Lebanese coast was also a major factor and an invasion of locusts in 1915 ruined crops. ${ }^{147}$

Even George Antonius, who has no love for the Turks, does not claim that Cemal deliberately organized the famine. He declares that the famine was due to several reasons, mismanagement, defective transport, currency depreciation, and, "above all ... profiteering and a dastardly collusion, for which no epithet would seem too strong, between Turkish officials and certain Syrian merchants." 148

145 Boustani, Histoire de la Grande Famine.

146 Mouawad, "1915-1918: La Grande Famine du Mont Liban."

147 There is extensive literature on the famine. Linda Schilcher, "The Famine of 1915-1918 in Greater Syria" in Problems of the Modern Middle East in Historical Perspective, ed. John Spagnolo (Reading: Ithaca Press, 1992), 229-258; Eddé, Beyrouth: La Naissance d'un Capital; Tamari, The Year of the Locust; Fawaz, A Land of Aching Hearts, 88-93, 96-100.

148 Antonius, The Arab Awakening, 203. 
In his declaration to the Paris Peace Conference Patriarch Elias Howeyk stated in no uncertain terms that "the population of Lebanon was decimated by a famine systematically organized by the enemy." He claimed reparations and demanded that the "Turco-German" enemies be made to stand trial for the "atrocities" such as the famine "which had wiped out one third of the population." 149

The famine is also reflected in the memoir literature. Of particular importance in this regard are the memoirs of Cemal Pasha. In the Turkish version of his memoirs, Cemal devotes an entire section to the famine, answering specific accusations that he had deliberately used the famine as a weapon of war to weaken potential opponents. In a deliberate effort to clear himself of blame, he resorts to very flowery language:

In my capacity as Army Commander I was in no way responsible for the provisioning of the population. But to see the suffering of all my beloved citizens was becoming unbearable. That was why I sometimes even supplied grain from army stores at the risk of exposing the army to starvation. ... ${ }^{150}$

In his memoirs, Cemal blames the usual suspects: local speculators, Sharif Husain, the Entente blockade etc. Cemal also stated that he wrote the section on the famine to answer the "slanderous lies" of the American Ambassador Morgenthau and the Dragoman of the Russian Embassy Mandelstam. ${ }^{151}$

On the issue of American aid and whether he would allow representatives of America or the Entente to supervise of the distribution of food:

I answered, it suffices that the supplies come, if they want I will set up a distribution committee consisting of representatives from America, Italy, Britain; I will even allow the distribution by representatives of the Entente. As long as these supplies arrive here and the people are saved from hunger. Because I have grown weary of having to witness the death in the streets of all these innocent citizens.... The Entente powers were telling the people (of Syria): "so you are dying of hunger anyway, at least start an uprising in

149 Hoyek, "Les Revendications du Liban," 239-240.

150 Cemal Pasha, Hatıralarım (Istanbul: İş Bankası, 2006), 341.

151 The issue of the famine does not appear in his Memoirs of a Turkish Statesman, which is curious considering that he was addressing principally his foreign detractors such as Morgenthau and Mandelstam. Henry Morgenthau, Ambassador Morgenthau's Story (Ann Arbor: Gomidas Institute, 2000); André Mandelstam, Le Sort de l'Empire Ottoman (Lausanne and Paris: Librarie Payot: 1917), 337: “The new national project [planned in 1916] was the extermination of the Syrians by famine." 
your country and throw the Turks out. Then we will give you everything you want. Far fewer of you will die during the uprising that from hunger." I had been charged with the sacred duty of defending six centuries of Ottoman presence in Syria and four centuries of attachment to the Caliphate. But these gentlemen forgot that it is not an easy thing to start an uprising in the lands that I govern. ${ }^{152}$

It is worth noting that in Hüseyin Kazım's memoirs we find the only direct reference in the memoir literature in Turkish to Cemal's admission that if the Christians died of hunger, this was not a bad thing. Kazım bears witness to his statement, "May the wretches perish, we will thus be rid of them!" ${ }^{153}$ Kazım, one of the last Turks to leave Lebanon, and who witnessed the Allied occupation, was summoned by the British authorities and specifically questioned on the famine and the government's responsibility for it. The famine also looms large in the memoirs of Ali Fuad Erden, who castigates the rich and powerful in Beiruti society for their indifference to the suffering of the poor. ${ }^{154}$

From mid-1916 onwards, Cemal was prevailed upon by Talat and Enver to moderate his rule of terror in Syria in order not to run the risk of "the Sharif being elevated to the status of a hero who would save the Arabs from the Turkish tyranny." The Arab Revolt was well under way and they wanted to keep their options open with a view to bringing Sharif Husain back into the Ottoman fold. ${ }^{155}$ Although Cemal had planned a third wave of executions he was told to put them off. ${ }^{156}$ This relative moderation was also reflected in Cemal's efforts to alleviate the horror of the famine by opening up soup kitchens and undertaking other forms of relief. Yet, for many it was a question of too little, too late. Father Louis Sheikho, whom we met above, wrote in his diary on May 5, 1916:

[Cemal Pasha had ordered that] a committee be formed consisting of the superiors of various convents and other religious houses to come to the rescue of the hungry. Yet we often hear these words attributed to Cemal

152 Cemal Paşa, Hatıralarım, 343

153 Huseyin Kazım Kadri, Meşrutiyettden Cumhuriyete Hatıralarım, see below, p. 70.

154 Ali Fuad Erden, Birinci Dünya Savaşında Suriye Hatıraları, see below, p. 135.

155 Çiçek, War and State Formation in Syria, 61-65. The Ottomans were negotiating with Faisal as late as May 1918.

156 Ibid., 60 . 
Pasha regarding the ravages of the famine in Lebanon: he said, "as long as the Lebanese do not eat each other they can still praise God." 157

At the beginning of 1917, according to Anbara Salaam, "for some reason I cannot fathom, the Ottoman authorities began to initiate relief operations." She and a few other ladies from the Beirut elite set up a committee to carry out relief work. ${ }^{158}$ The mobilizing of the Beirut ladies for charity work by Azmi Bey (the governor of Beirut) is also mentioned by Bayard Dodge of the Syrian Protestant College, who somewhat caustically remarked,

He himself organized some of the wealthy ladies of the higher circles of society and started many charities. . . . He did interest the selfish leaders of Beirut society and forced them to give time and money to the poor. A number of wealthy women who had never thought of doing anything unselfish proved themselves capable workers and saved hundreds of lives. ${ }^{159}$

By mid-1917, Cemal Pasha and Azmi Bey, as well as the Mutasarrıf of Mount Lebanon, Ali Münif Bey, seem to have actively undertaken relief work. On April 13, 1917 Cemal sent the following cipher telegram to Istanbul:

I am copying to you the telegram I have sent to the Vilayet of Beirut concerning the provisioning of Mount Lebanon. . . . I have estimated that until the next harvest at least one hundred and fifty thousand liras are needed for the provisioning of the poor of Mount Lebanon. I propose to raise this money by putting up as a gage the property and enterprises of the Maronite Church. The money thus raised will not be given to the Maronite Patriarchate but will be put at the disposition of a special committee constituted by the Vilayet of Beirut for the purchase of grain from the army stores.

I have read the letter from the Maronite Patriarchate [speaking of] the great suffering of the people of the Mountain where every day hundreds of children are dying of hunger and asking for the army to provide relief. This letter was brought by a special commission of three lay personages and a bishop. ${ }^{160}$

157 Tautel and Wittouck, Le Peuple Libanais dans La Tourmente de la Grande Guerre, 63.

158 Khalidi, Memoirs of an Early Arab Feminist, 71-72.

159 American University of Beirut Archives, Howard Bliss Collection, Box 18 AA2-3-2. Report on the Abeih and Suk al Garb soup kitchens, by Bayard Dodge. Dodge was Howard Bliss's son-in-law and an active participant in relief work.

160 Başbakanlık Osmanlı Arşivi (BOA), Ottoman Archives, DH-I-UM 20/2, Commander of the Fourth Army Cemal Pasha to Grand Vezirate, 30 Mart 1333 (April 13, 1917). 
Ivi | Introduction

Cemal instructed Azmi Bey to "receive the commission [from the Patriarchate] cordially and carry out with them extensive consultations about what can be done ... for the provisioning of the Mountain." ${ }^{161}$ Azmi Bey was also very active in setting up soup kitchens. He wrote to Istanbul on March 26:

I thank you for the two thousand liras for the provisioning of the poor. In the past four months in the city of Beirut sixty thousand poor have been fed. They are given free of charge, bread and a meal. Three thousand children are being fed and educated in orphanages.... Two thousand liras are sufficient funds for only one week for this charity work. I am about to open more soup kitchens for the feeding of thousands of poor from the Mountain who, as of tomorrow will be unable to find even a mouthful of bread. Thousands are dying each day. The government which is obliged to help must send fifty thousand liras. ${ }^{162}$

Anbara Salaam appreciated Azmi Bey's efforts, "Azmi Bey was the person we resorted to for all our needs. He was a hardworking man in touch with every issue, large and small, that concerned the city and its inhabitants. ..."163

The soup kitchens and other relief works were inadequate given the scale of the famine. The funds sent by Istanbul were utterly insufficient. Indeed, competition over scarce resources seems to have developed between Azmi Bey and Ali Münif Bey. Bayard Dodge commented: "[A] $t$ the beginning of the new year, that is January 1917, a new development occurred. The Governor of Mount Lebanon disregarded the strict attitude of his neighbor, the Governor of Beirut. . . Perhaps his conscience was bothering him, because it was he who had been one of leading spirits in cornering the wheat market. . ." Regarding Azmi Bey, Dodge stated that he had done a great deal to offer succor to orphans and the poor, setting up hospices, work houses, and soup kitchens: "His plans sounded splendidly and many persons sang his praises at first, but after a while the hospices became run down, the children were very much underfed and the citizens of the city turned against the Governor in a most bitter way." 164

161 Ibid. There are some twenty documents in this file, all dealing with soup kitchens and orphanages.

162 Ibid. Governor of Beirut Azmi Bey to the Ministry of Interior. 13 Mart 1333 (March 26, 1917).

163 Khalidi, Memoirs of an Early Arab Feminist, 73.

164 American University of Beirut Archives, Howard Bliss Collection, Box 18 AA2-3-2. 


\section{Azmi Bey wrote:}

[For charity work] we are spending ten thousand liras a month. It is without doubt that the population of the Jabal was more than three hundred thousand before the war. Forty five thousand of these have moved to Beirut. Fifty thousand have gone to Jabal Druze [Hauran]. This year some seventy thousand have died. This leaves [in the Mountain] a maximum of two hundred thousand. In Beirut we have a population of one hundred and fifty thousand. ... There is no doubt that Ali Münif Bey is favoring the Jabal. .. ${ }^{165}$

Azmi Bey constantly complained that he had insufficient funds for relief work and requested that the ten thousand liras provided be increased to twenty thousand a month. Talat Pasha personally cabled him, stating: "Given the present state of the treasury for now it is not possible to increase the sum and you are requested to make do with the money sent." 166 What is striking about these documents is the frank and open admission that thousands were dying of hunger and Azmi Bey's sincere statement that seventy thousand people had died in the Mountain within a year.

The issue of famine relief and charity work was taken in hand at the highest levels of state. On July 1, 1918, Enver Pasha wrote,

[The following sums] have been sent to the Ylldirım Army Group command. Twenty thousand liras for the poor of Beirut and Mount Lebanon, two thousand five hundred liras for the orphanage at Antoura, forty-two thousand liras for the poor of Damascus. This makes a total of sixty-two thousand five hundred liras. Any monies spent from these sums must be accounted for every three months. ${ }^{167}$

There are two interesting things about this document. The first is that just months before the Ottoman surrender on October 30, 1918 the government was sending funds for relief work in Syria and no lesser a personage than Enver Pasha himself had taken the matter in hand. At the very least, this complicates the "famine as genocide" thesis. The second is the order

165 BOA DH-I-UM 20/2, Governor of Beirut Azmi Bey to the Ministry of Interior, 22 Mart 1333 (April 4, 1917).

166 BOA.DH.ȘFR 75/2 1 Nisan 1333 (April 14, 1917), Minister of Interior Talat Pasha to the Fourth Army Command.

167 BOA DH. ŞFR. 88/163, cipher from Minister of War Enver Pasha to Vilayet of Syria, 18 Haziran 1334 (July 1, 1918). The Ylldırım (Lightning) Army Group was the last desperate plan on the part of Enver to recover Baghdad. It was later diverted for the defense of Palestine. Rogan, The Fall of the Ottomans, 342-343. 
to "provide accountability every three months." Evidently, Enver at least (who admittedly was not the most realistic of men) believed that all was not yet lost. However, the monies being quoted in the letters were in Ottoman paper money that was greatly devalued at the time. The total of sixty-two thousand five hundred liras was pittance compared to the enormity of the crisis. $^{168}$

It is worth asking the question why the Ottoman authorities in Syria decided to undertake humanitarian work in 1916. One possible answer is that the Allied press, particularly the French, had started a vociferous campaign against Cemal Pasha, declaring that he was deliberately starving the Christians. Hüseyin Kazım states in his memoirs that Cemal started the famine relief after damning articles appeared in the French press. He referred particularly to an article in Le Temps. Although Kazım did not give the precise date, articles such as the one below began to appear in mid-1916:

The Tragic Situation in Lebanon. For nearly four months the Turks have started a massacre of the Lebanese population.

[For Cemal Pasha] the time was ripe for the execution of his plans for the extermination of the Christians of the Orient. . . The eyewitness who visited Lebanon spoke of nearly 80,000 victims up to 10 May, when he left. The mind boggles at the ravages of the double plague, that of the Turks and of the famine which has struck Lebanon. ${ }^{169}$

A few months later, the same paper ran a story entitled, "The Turks are starving Lebanon," which stated that the visit of Enver Pasha to Syria had resulted in a "veritable calamity" for the population. Enver, the article claimed, had given strict orders that no grain was to be allowed into the Mountain. As a result, thousands were dying, and the roads "are covered in cadavers." A delegation of notables had gone to Ali Münif Bey, the Mutasarrif of Lebanon to ask him to address the situation. Ali Münif told them to mind their own business: "This is a matter for the government not private individuals. When the Lebanese start devouring each other only

168 By mid-1918 the rate of the paper lira to gold was 4.5 paper liras to one gold lira, thus 62,000 liras does not amount to much. It should be recalled that Azmi Bey stated that he was spending 2,000 liras a week for famine relief work in Beirut alone. See footnote number 97. My thanks to Şevket Pamuk for this information. See also Şevket Pamuk, A Monetary History of the Ottoman Empire (New York: Cambridge University Press, 2000).

169 Le Temps, June 27, 1916, accessed February 7, 2017, www.gallica.bnf.fr/ark:/12148/ bpt6k2425894. 
then will you be able to claim there is a famine." What is remarkable here is that the famous statement "when the Lebanese eat each other," which is commonly attributed to Cemal, is here reported as having come from Ali Münif. ${ }^{170}$

Almost a year later the influential French journal L'Orient Arabe ran an article based on the testimonies of American missionaries who had recently left Syria, stating that "numerous cadavers in the streets have become a common sight." The article did, however, state that four or five soup kitchens had been opened at the initiative of Omar Da'uq and Münif Bey. The governor of the Mutasarifiyya had openly told the American relief committee that "every day he was registering one thousand deaths." The article also mentioned war profiteering as a cause for the famine. The first reason given for the famine was, "the well-known aim of the Turkish government to kill the Arab element which is defying it, or at least to reduce it to a condition where it can do no harm." ${ }^{171}$ It is worth noting that this article coincides with the efforts mentioned in the documents above to create soup kitchens and work houses and to generally alleviate suffering.

\section{The last days in the overall context of the Great War}

What was going through the minds of the Young Turk leadership at this time? How could they be making what were clearly long term, or at least medium term, plans up to the last few months before the collapse? What were they counting on? Here it is important to do a synchronous evaluation of events in the Ottoman theater and those of the Western Front. In 1917 the war was going badly for the Entente. On April 17, French forces failed to take Arras and the mass slaughter of repeated futile offensives led to a mutiny among the troops. In the same year, the British offensive was bogged down in Flanders. In late spring German submarine warfare came close to knocking Britain out of the war. Britain was shaken by several mass strikes by an increasingly radicalized labor force. Most stupendous of all, the Russian front collapsed and an armistice was signed on December 17, followed by treaty at Brest-Litovsk on March 3, 1918. ${ }^{172}$

170 Le Temps, November 6, 1916.

171 L'Orient Arabe, October 20, 1917.

172 Michael S. Neiberg, "1917: Global War," in Winter, The Cambridge History of the First World War, vol. 1, 110-132. 
Ix Introduction

Brest-Litovsk was indeed a game changer. "The Treaty of Brest-Litovsk represented an enormous success for the Ottomans." The Bolshevik seizure of power and the collapse of the Russian Caucasus Army on the eastern front released a great number of veteran troops that Enver now wanted to use to retake Baghdad and Palestine from the British. Talat was to negotiate in person at Brest-Litovsk and when the news of the revolution reached him he was to declare that peace was at hand as the Allies would now have to come to terms. "Futher, he emphasized, only negotiations could end the war." ${ }^{173}$

The Ottomans thus secured their 1877 frontiers with Russia and the peace with the Bolsheviks enabled the transfer of thousands of troops to other fronts, notably Palestine. "The Young Turks were thus prime beneficiaries of the Treaty of Brest-Litovsk." ${ }^{174}$

It must also be recalled that in the same year the Gaza front was holding firm and by April 1917 it was being said among the British ranks that "Gaza was another Gallipoli." 175 Interestingly, the Gaza-Gallipoli equation was also made by Ottoman troops defending the region. When an officer asked one of them whether he thought the British would come again after the Second Battle of Gaza, a seasoned veteran of Gallipoli replied, "No, Effendi, they will not, they have seen our regimental insignias," meaning that the enemy had seen that they were up against the foe who had already defeated them. ${ }^{176}$

Even after Allenby's breakthrough at Beersheba on October 31, 1917 and the decisive victory at Gaza on November 6-7, although in full retreat, the Ottoman army was not broken. ${ }^{177}$ Their German ally was winning on the Western Front and nobody thought the end of the war was close.

After the fall of Jerusalem on December 9, 1917, the Ottoman forces made "an astonishing recovery." ${ }^{178}$ In May 1918, Küçük Cemal sent Shukri Pasha Al Ayyoubi to Emir Faisal to sound him out on possible negotiations, promising his father full autonomy on the condition that he abandon claims to independence. Faisal by this time had no reason to trust the

173 Michael A. Reynolds, Shattering Empires. The Clash and Collapse of the Ottoman and Russian Empires 1908-1918 (Cambridge: Cambridge University Press, 2011), 162, 189, 190.

174 Rogan, The Fall of the Ottomans, 357.

175 Faulkner, Lawrence of Arabia's War, 255.

176 Falih Rıfkı Atay, Ateş ve Güneş, 99.

177 Faulkner, Lawrence of Arabia's War, 342.

178 Rogan, The Fall of the Ottomans, 329. 
CUP. Indeed, the Ottoman authorities in Istanbul "were optimistic about the outcome of the war" and planned to replace Sharif Husain after the war with Sharif Ali Haidar. ${ }^{179}$

Just months before the armistice, in July 1918, Enver was instructing his subordinates to provide quarterly accounts of their spending for relief work. Just before he left Syria, Cemal sponsored and published two encyclopedic works on the Vilayet of Beirut and the Mutasarrifiyya of Mount Lebanon. Even well after the American entry into the war, Dr. Howard Bliss was writing to Cemal Pasha, who had long since left Syria, in the most affectionate terms on May 20, 1918, telling him that the College remembered him fondly,

[F]or all you have done for the cause of education in Syria and of course your many favors to our College... . We are looking forward to the next autumn when we hope to resume our work on October 9. We miss Your Excellency very much but it is a great comfort to know that although you are far away and occupied with many great affairs Your Excellency does not forget us and that in you we have a strong, just, and constant friend. ${ }^{180}$

Evidently, the good doctor was still hedging his bets in case the college had to contend with a world where the Turks retained control of Beirut. Again, we have to shift our gaze to what was happening on the Western Front. In the spring and early summer of 1918 , the German spring offensive seemed likely to succeed. ${ }^{181}$ At the very least the leadership of the Young Turks may have thought that they could secure a place at the table for a negotiated peace which would allow them to keep some of their Arab provinces. The much belated efforts to provide famine relief can also be seen in this light. Bad press in the west would not look good if the Ottoman state was to take its place at the negotiating table. The recall of Cemal in 1917 and his replacement with Mersinli [Küçük] Cemal Pasha, who was much more

179 Çiçek, War and State Formation in Syria, 64, 65.

180 American University of Beirut Archives, Howard Bliss Collection, Box 18, AA 2-3-2, May 20, 1918, Howard Bliss to His Excellency Ahmed Djemal Pasha Minister of Marine Constantinople. The United States broke off diplomatic relations with the Ottoman Empire but never actually declared war against it, hence the college was allowed to continue teaching. The very same Howard Bliss waxed lyrical after the fall of Jerusalem just five months previously, crowing, "Jerusalem has been redeemed." See Plate 10: Cemal Pasha's visit to the Syrian Protestant College in 1917.

181 Christoph Mick, "1918: Endgame," in Winter, Cambridge History of the First World War, vol. 1, 133-171. 
favorably regarded by the Arabs, can be seen as an attempt to repair the damage done and possibly win back Arab favor after the war. Some Arab intellectuals actually felt that, "Mersinli was expressly appointed by Istanbul in order to control the damage towards the Ottoman state brought about by the actions of Ahmad Cemal." 182 There is evidence that Cemal Pasha had high ambitions for his political future after the war. A group of influential CUP members, "[h] aving come to the conclusion that the Ottoman Empire had lost the war, believed that what was needed was a new policy under a new grand vizier, namely Djemal Pasha." It was hoped that because Cemal had a reputation as a relative moderate in the eyes of the victors he might procure more lenient peace terms. ${ }^{183}$

Although, as Sean McMeekin has shown in his admirably documented book, the Turkish-German alliance was stretched to breaking point in the final two years of the war, it is an overstatement to declare, as he does, that "[f]or Berlin, the Turks were no more than a tool to exploit the resources of the Orient-a tool which was now long past its expiration date." ${ }^{184}$ By his own admission, the Germans actively encouraged Enver's push into eastern Anatolia and the Caucasus in the aftermath of Brest Litovsk. As the Russian armies collapsed in the spring of 1918, the Germans endorsed the stipulation in the final treaty of Brest-Litovsk that "Russia shall do everything to in her power to guarantee a speedy and orderly return of the East Anatolian provinces to Turkey." In less than two months the Ottoman Third Army had reversed all of the Russian gains of the last three years. Thus the Ottoman Empire secured a return to the pre- 1877 borders with Russia with the blessing of the Germans. ${ }^{185}$ Ultimately, in the Caucasus, the Ottoman forces were almost too successful for the taste of their German allies and the TurcoGerman competition for the possession of the oil rich Baku region actually led to skirmishes between the Ottoman "volunteers" and the Germans. ${ }^{186}$

But in 1917 and well into 1918 the Germans had certainly not given up on the Ottomans. No lesser a personage than Erich von Falkenhayn, the

182 Salim Tamari, "Arabs, Turks, and Monkeys. Ottoman Ethnographic Mapping of Palestine and Syria," in Salim Tamari, The Great War and the Remaking of Palestine (Los Angeles: University of California Press, 2017).

183 Talha Çiçek, "Myth of the Unionist Triumvirate, The Formation of the CUP Factions and Their Impact in Syria during the Great War," in Çiçek, Syria in World War I, 9-36.

184 McMeekin, The Berlin-Baghdad Express, 333.

185 Ibid., 330. The Ottoman provinces of Kars, Ardahan, and Batumi had been ceded to the Russians by the Treaty of Berlin in 1878.

186 Reynolds, Shattering Empires, 217. 
ex-commander in chief of all German armies, was sent to take command of the The Ylldırım Army Group in 1917. The Ylldırım Army Group, was originally designated for the recapture of Baghdad, but diverted, at the insistence of Liman von Sanders, for the defense of Palestine, was almost entirely staffed by German officers. A "full German infantry division" was sent to the Palestine front, and the Germans committed " $\mathfrak{E} 5$ million in gold-extremely scarce resources in mid-1917-to ensure Yildirım had the resources to succeed"187 Despite (admittedly serious) mutual tensions, the Germans and the Turks fought tooth and nail to stem the British advance. If the Ludendorf offensive had succeeded in the spring of 1918 (as it very nearly did) the Turks would have quite probably demanded some quid pro quo in the Arab provinces from their German allies.

They certainly would have felt that they deserved to be fairly treated by Germany, as much to the world's surprise, Germany's major ally in the Great War had turned out to be not Austria-Hungary (whose defeats at the hand of tiny Serbia and Russia had in fact made it a liability), but the Ottomans. It were the Ottoman troops that had helped stem the Russian advance into Galicia and hence onto Vienna. The victory at Gallipoli had indirectly contributed to the advent of the Russian revolution by denying sea access to Russia and any potential support from the Entente. The victory at Kut-al-Amara had gained the Ottoman Empire tremendous prestige in the Muslim world. ${ }^{188}$ Even the two attempts against the Suez Canal, although they failed, pinned down tens of thousands of British and colonial troops in Egypt, troops that could otherwise have been invaluable on the Western Front. McMeekin himself admits that "[i]n the annals of the First World War, the successful Turko-German Sinai desert crossing has to count as one of the greatest achievements." ${ }^{189}$

\section{Curious interludes: Anglo-American attempts to make a separate peace with the 0ttomans}

One of the most ambiguous (and understudied) grey areas of the Great War remains the possibility of a separate peace between the Ottoman Empire and the Entente. It appears that as early as mid-1916, after the victories of

187 Rogan, The Fall of the Ottomans, 342-343. "The Yildırım Group was to be organized along the lines of a German army group."

188 Ibid., 267: "With a loss 13,309 in total Kut was the British armies' worst surrender ever."

189 McMeekin, The Berlin-Baghdad Express, 174. 
Gallipoli and Kut-al-Amara, the Germans were worried that Istanbul would make a separate peace. German emissaries reassured Berlin that Enver and Talat had told them that they would continue the war to its end..$^{190}$ Later in the war, attempts were made by American and British diplomats to separate the Ottoman Empire from her German ally. In May 1917, according to the suggestion of Henry Morgenthau, the former US ambassador to the Sublime Porte, President Wilson, "approved a secret mission to sound out the the Ottoman government for a separate peace." ${ }^{191}$ Morgenthau told Secretary of State Robert Lansing that conditions were ripe for such a plan as Enver, Cemal, and Talat were "heartily sick of their German masters." He proposed that he should go to Switzerland where he would meet "two members of the Ottoman Cabinet." His local man was Arshag Schmavonian, who had been Morgenthau's Armenian dragoman in Istanbul. Morgenthau told Lansing that Schmavonian was in constant touch with the Ottoman authorities and that he should accompany him on his mission. ${ }^{192}$

Secretary Lansing sounded out the British Foreign Secretary Balfour who was in Washington. Balfour replied that although he had nothing definite to go on, he was aware that the Ottomans were "nibbling." However Balfour stated that as Switzerland was "simply overrun with spies, Morgenthau should proceed to Egypt from where he could easily establish contact with the Ottomans. His ostensible cover was that he would be travelling to Egypt to investigate the conditions of the Jews in Palestine.

This bizarre plan came to nothing. It seems that Wilson changed his mind as a result of the determined intervention of the Zionist lobby, led by Justice Brandeis. Documents in the archives of the American University of Beirut originating from Special Agent William Yale, the American liason officer attached to the British Expeditionary Force in Egypt, show that the Zionists were very much opposed to a separate peace with the Ottomans that would endanger their plans for a Jewish homeland. Morgenthau was waylaid in Gibraltar where he was met by leading British Zionist Chaim Weizmann and the French Zionist Weil. Weizmann would later recount

190 Ryan Gingeras, Fall of the Sultanate. The Great War and the End of the Ottoman Empire, 1908-1922 (Oxford: Oxford University Press, 2016), 131

191 Nevzat Uyanık, Dismantling the Ottoman Empire. Britain, America and the Armenian Question (London: Routledge, 2016), 62. It must be recalled that at this point the United States had not entered the war. The United States would ultimately break off diplomatic relations with the Ottomans but would never declare war against it.

192 Ibid., 63. Dragomans were the official translators attached to foreign missions in the capital. 
his cloak and dagger mission to Yale. According to Yale, Morgenthau had exceeded his instructions and had his knucles rapped in no uncertain terms by President Wilson. Yale also stated that Bogos Nubar, the leader of the Armenians nationalists, had told him in Paris that the famed Schmavonian was "the creature" of the Young Turks and was widely mistrusted by the Armenian community. Yale also pointed out that the British had been against the plan from the outset but did not want to offend Wilson by opposing his "pet plan." ${ }^{193}$

William Yale recorded in his private papers that in 1920 he had a memorable conversation with Dr. Chaim Weizmann on an Italian cruise ship bound from Trieste to Alexandria where the two men had a fortuitous meeting. He declared that he was "so astonished" by what Weizmann told him that he was "able to recall it word for word." Weizmann stated that he had been sent by Balfour with the specific instructions to scuttle Morgenthau's "secret mission." He and Weil told the ex-Ambassador that the Zionists in Britain and America were very much against a separate peace with the Ottomans because they wanted a Jewish homeland under British, not Turkish, rule. He even threatened that if the attempt were to go ahead Wilson would lose the support of the Zionist lobby in America and Britain. Yale recorded that Weizmann told him,

On your national holiday, the Fourth of July, in Britain's greatest fortress, with British sentries facing outside the windows, three Jews decided whether or not to make a separate peace with the Turks. ${ }^{194}$

Morgenthau's ill-fated "secret mission" was followed by a British initiative in December 1917 to "detach the Ottoman Empire from German domination." What worried the British was the unravelling of Russian power in the Caucasus which would grievously threaten British interests in Iraq and Iran if Germany was allowed to fill the vacuum. Since the United States was not actually at war with the Ottoman Empire, Lloyd George felt that a "proper American" should be found to undertake such an approach. $\mathrm{He}$ had in mind Morgenthau's successor as US ambassador, Abraham Elkus.

193 AUB Archives Bayard Dodge Papers. AA 2-3-2-19-4. This is a remarkable hand-written document which is clearly a draft that William Yale would later include in his papers. It is entitled “Ambassador Henry Morgenthau’s 'Special Mission' of 1917 by William Yale."

194 Ibid., 11. 
The plan came to nothing because of the rapidly changing conditions in the region. ${ }^{195}$

Although neither of these plans for a separate peace came to fruition, the Ottomans must have been aware of their existence, particularly as Morgenthau's so-called "secret mission" was no secret at all. The New York Times published an article that stated that Morgenthau was on his way to make a separate peace with the Turks, and US Ambassador in Istanbul, Abraham Elkus, stated that "it was well known everywhere that Ambassador Morgenthau was on his way." 196 The Ottomans must have been enheartened by such an attempt that they must have perceived as a strengthening of their eventual bargaining position. ${ }^{197}$

The end is well known. The Palestine front collapsed as Allenby stormed through Palestine in September 1918, and the German breakthough in the Western Front was halted the same summer. ${ }^{198}$ In the end, the German and Ottoman surrenders occurred at almost the same time. The Mondros Armistice (October 30, 1918) narrowly preceded the surrender of Germany (November 11).

Two of the writers featured in this book actually witnessed the very last days of the Turkish presence in Beirut. Hüseyin Kazım recounts in detail how some eight hundred Turkish families were stranded in Beirut after the Allied occupation and how he entreated the Allied authorities to procure a ship to evacuate them. Münevver Ayaşlı also saw the arrival of the British troops as they awaited evacuation. Hüseyin Kazım thanks Omar Bey Dauk, the head of the Municipality of the city, profusely for his help in alleviating the dire conditions of the last Turks in Beirut. Dauk declared that he was put in charge personally by the last Ottoman Vali of Beirut, Ismail Hakkı Bey. On October 1, 1918 Omar Dauk announced that Ismail Hakkı Bey had handed him a letter, declaring as follows:

To all officials in general: In consequence of the proclaiming of the Arab Government, the city has faced an accomplished fact; therefore the administration of the government has been handed over to the head of the

195 Uyanı, Dismantling the Ottoman Empire, 76.

196 AUB Archives. “Ambassador Henry Morgenthau’s 'Special Mission.” 12.

197 No doubt, much more research is required on the issue of separate peace proposals to the Ottomans. I have not been able to access the Ottoman archives on this issue.

198 Rogan, The Fall of the Ottomans, 373-380. 
Municipality. As a result of this state of things your offices have lapsed. I therefore make these changes known to you and bid you to act accordingly. 199

Regarding the Turkish families who had remained in the city, Dauk Bey made the following declaration:

In view of the fact that the Turkish officials and their families, and the rest of the strangers constitute for us a trust everyone should take care to provide for their ease and security such as it is demanded by the Arab Government. ${ }^{200}$

So ended four hundred years of Ottoman rule in Syria.

What follows is an attempt to glimpse the mindset of some of the Ottomans who witnessed the twilight of the Empire in the Arab lands.

\section{Notes on names, spelling, transliteration, and choice of passages translated}

The family names of the authors used in this book would have been taken following the adoption of the Surname Law of 1934. Thus Ali Fuad took the surname Erden, Falih Rıfkı became Atay, Naci Kaşif would adopt the name Kıcıman, Hüseyin Kazım would adopt the name of his father, Kadri. Münevver Ayaşlı used her married name in her writings. In this book, I have used the name the actor in question would have called himself/herself at the time.

I have endeavored to consistently use the Turkish version of the name if the person is Turkish, hence Cemal, not Jamal. For Arab names I adopted the Latin spelling used by recognized works such as George Antonius's Arab Awakening.

In the choice of passages translated, I focused on sections of text that illustrate the mentality of the writer. I have left out long discussions of detailed military campaigns and skirmishes, except when they have a direct bearing on the mentality of the actor. I have translated the original subheadings in Turkish, sometimes I have felt the need to add another subheading for the sake of clarity, for example, Tripot [Tripod. Gallows. The hanging of the Arab martyrs]. The main body of the text which consists of

199 American University of Beirut Archives, Howard Bliss Collection, Box 18 AA 2-3-2 18-6. In English translation in the file.

200 Ibid. 
Ixviii | Introduction

translations has not been put in quotation marks. My interventions in the main text appear in brackets and are in italics.

Each of the following five chapters aims to reflect the perception of the last days of the Ottoman Empire in the Arab lands through the prism of the five actors mentioned above. All of the perceptions are ex post facto, that is to say, they are heavily colored by the postwar ambience of republican Turkey. Thus, Falih Rifkı Atay is scathing about the "waste" of men and resources for what he later came to see as a lost cause. Ali Fuad Erden, a professional soldier, sought to position himself as an observer and not a military historian. Hüseyin Kazım Kadri is indeed trying to set the record straight by stating at the very outset of his memoirs that he is writing "not as a historian but as a witness." Naci Kicıman sees himself as an intermediary, a go-between the events of the siege of Medina and his much revered commander Fahreddin Pasha. Münevver Ayaşl1, who is writing some forty years after the events is positioning herself as a very late Ottoman avant la lettre. 